University of Rhode Island

DigitalCommons@URI

Open Access Master's Theses

1977

\title{
Landmarks Preservation in New York City: a Critique
}

Karen Ansis

University of Rhode Island

Follow this and additional works at: https://digitalcommons.uri.edu/theses

\section{Recommended Citation}

Ansis, Karen, "Landmarks Preservation in New York City: a Critique" (1977). Open Access Master's

Theses. Paper 1354.

https://digitalcommons.uri.edu/theses/1354

This Thesis is brought to you for free and open access by DigitalCommons@URI. It has been accepted for inclusion in Open Access Master's Theses by an authorized administrator of DigitalCommons@URI. For more information, please contact digitalcommons-group@uri.edu. 
LANDMARKS PRESERVATION IN NEW YORK CITY:

A CRITIQUE

by

KAREN ANSIS

A THESIS SUBMITTED IN PARTIAL FULFILLMENT OF THE REQUIREMENTS FOR THE DEGREE OF MASTER OF COMMUNITY PLANNING

UNIVERSITY OF RHODE ISLAND

1977 


\section{MASTER OF COMMUNITY PLANNING THESIS}

OF

KAREN ANSIS

Approved:

Thes is Committee:

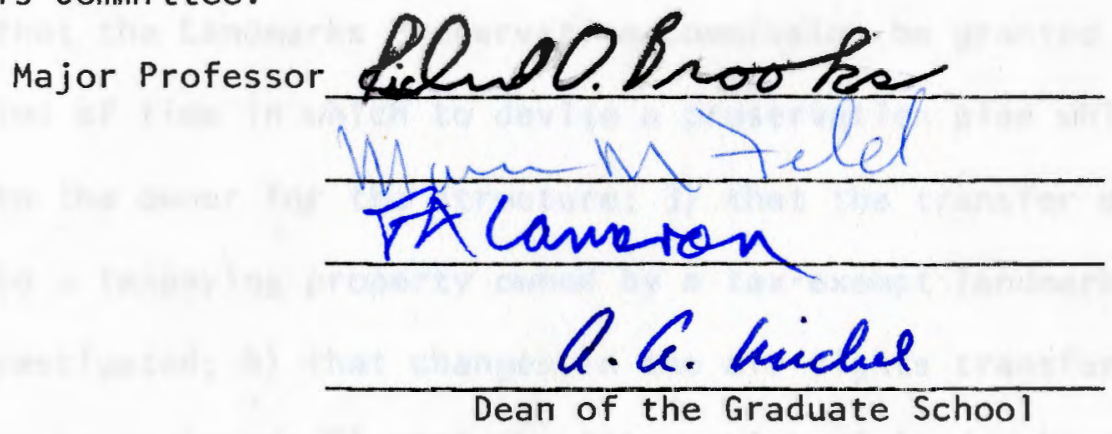

UNIVERSITY OF RHODE ISLAND 


\section{Abstract}

Along with a substantial increase in interest in historic preservation in the last decade has come an acute awareness that landmarks preservation is a real estate, planning, and development activity which frequently involves extensive costs and difficult market decisions.

In response to the needs to assuage and resolve financial and legal conflicts and to establish equitable public policy regarding the built environment, in 1965 the City of New York enacted one of the most innovative and progressive landmarks preservation statutes in the country. Because this law has served as a model for other localities and because this law has been successfully challenged in litigation, its strengthening and the strengthening of the framework for landmarks preservation in New York City are pressing concerns for preservationists.

In an effort to make landmarks preservation more practicable, in the spring of 1975 a committee of prominent lawyers in the city met and discussed six legal approaches for improving landmarks preservation. The approaches were: 1) that the standard for judging hardship for charitable institutional owners of landmarks entail the concept of general usability; 2) that the Landmarks Preservation Commission be granted a reasonable period of time in which to devise a preservation plan which is acceptable to the owner for the structure; 3 ) that the transfer of a tax abatement to a taxpaying property owned by a tax-exempt landmark landlord be investigated; 4) that changes in the air rights transfer laws in the city be reviewed; 5) that the integration of landmarks preservation into the City's master plan and zoning ordinance be explored; and 6) that the establishment of a city agency to lease space in and manage landmark properties should be examined. 
Subsequent to a presentation of the economic and legal frameworks for historic preservation in the thesis, each of the above approaches is assessed and it is concluded that the approaches, as stated, will not have a serious and positive impact on landmarks preservation efforts. Recommendations for expanding the approaches and for other means of encouraging landmarks preservation--federal income tax incentives, easements programs, new funding sources, and public education programs--are then suggested. 
TABLE OF CONTENTS

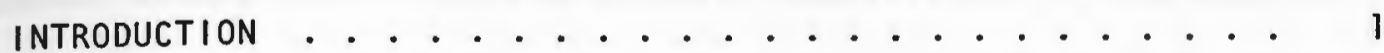

I. THE ECONOMIC FRAMEWORK FOR LANDMARKS PRESERVATION

IN NEW YORK CITY . . . . . . . . . . . . . . . . . . . . 4

A. General Overview ................. . . . 4

B. The State of Real Estate in New York City........ . 5

C. Development Rights Transfers . . . . . . . . . . . 11

D. Adaptive Uses of Landmarks . . . . . . . . . . . . 16

E. Conclusions... . . . . . . . . . . . . . . 23

11. THE LEGAL FRAMEWORK FOR LANDMARKS PRESERVATION

IN NEW YORK CITY . . . . . . . . . . . . . . . . . 26

A. Federal Involvement in Historic Preservation . . . . . 26

B. State Involvement in Historic Preservation . . . . . . . 32

C. Landmarks Preservation in New York City . . . . . . . . 33

D. The Problems of Preserving Landmark Structures . . . . 40

E. Conclusions... . . . . . . . . . . . . 45

111. APPROACHES FOR STRENGTHENING LANDMARKS PRESERVATION

A. The Ad Hoc Committee to Strengthen the
Landmarks Preservation Law . . . . . . . . . . 46

B. The Structure for Assessing the Approaches . . . . . . 49

C. Critique and Summary Charts........... . 50

IV. CONCLUSIONS AND SUGGESTIONS . . . . . . . . . . . . . . . 66

A. Expanding the Approaches .. . . . . . . . . . 66

1. Re-Use ................... . . 68

2. Tax Structures ............... . . 73

3. Restructuring the Administration of

B. Additional Areas for Strengthening Landmarks

Preservation ............ . 79

1. Preservation Incentives ............ . 79

2. Funding Sources.................. . 81

3. Public Education ............. . 83

C. Summary .. . . . . . . . . . . . . . 86 


\section{Introduction}

Historic preservation is not, as many believe, a cultural affairs activity. In most cases, saving a landmark building is a planning and development effort which requires property acquisition, bricks and mortar work, real estate and management expertise, litigation, and a great deal of administrative time; saving a landmark requires money.

Raising funds for historic preservation is often difficult. Few public and private foundations have program categories for historic preservation, and financial aid from the government is limited. The private profit-making sector views preservation as one of many possible charitable activities which business might undertake, and cannot, therefore, be consistently relied on for money. And, as will be shown in Chapter 1, the real estate market itself does not encourage landmarks preservation.

These factors and the proposition that historic preservation serves an important public purpose prompted the enacting of federal, state, and local laws which encourage the protection and preservation of architectural, historic, and cultural resources. "In 1965, there were fewer than one hundred municipal preservation commissions; today there are more than 450 cities and towns that have landmark or historic district commissions." 1 Both public regulation of historic properties and citizen participation in preserving landmarks have grown immeasurably in recent years. This support, combined with the widespread belief that historic preservation positively contributes to neighborhood revitalization and stabilization, forms the basis for an assumption of this thesis: that landmarks preser1James Biddle, "Historic Preservation: The Citizen's Quiet Revolution,"
8 Conn L R 203 (Winter, 1975-76). 
vation is a worthwhile activity which merits the investment of human and financial resources from the public and private sectors.

The first two chapters of the paper look at the problems--especially the real estate and legal difficulties--of landmarks preservation in New York City. In 1965, New York City enacted one of the most progressive and innovative preservation statutes in the country. That this law has been successfully challenged and weakened is of great consequence to other municipalities which have based or are in the process of basing preservation laws on the New York City model. Chapter III presents six approaches, discussed by a special committee of lawyers, for strengthening landmarks preservation in the $\mathrm{City}$, and an evaluation of the committee's proposals. The final chapter states the conclusions of the assessment--that important legal problems cannot be readily solved--and provides suggestions for other means for encouraging landmarks preservation. The author does not attempt to resolve several important problems of landmarks preservation: the development of specific architectural criteria upon which landmark designations can be made, and the taking and equal protection issues which are prompted by regulations imposed upon landmark owners.

To facilitate readers' understanding of this paper, it is necessary to define certain terms at the outset: "renovation" and "rehabilitation" are used interchangeably and mean the improvement of the structure to meet building and housing code standards; "conversion" means the changing of the use of a building, for example, from a warehouse to an apartment house; "restoration" refers to the return of a structure to its original appearance; "adaptive use" refers to the renovation or conversion of a building in a manner which retains its significant architectural features; "preservation" refers to the active maintenance of the character of the structure and does not necessarily mean "restoration"; "landmarks preservation" and 
"historic preservation" are used interchangeably. 
CHAPTER I: THE ECONOMIC FRAMEWORK FOR LANDMARKS PRESERVATION
IN NEW YORK CITY

\section{A. General Overview}

An economically "healthy" building is one which generates a positive yearly cash-flow figure to the extent that investment in the property is justified. This amount is generally calculated by subtracting maintenance and operating costs, taxes, and debt service from the rental income of the structure. The economic viability of a building, then, is the structure's ability to earn sufficient revenues in excess of expenses to yield a competitive profit for the owner. The possible consequences of the failure of property to operate in the black range from increases in rents to the disuse, neglect, and eventual loss of the building.

Landmark buildings compose a special class of real estate. In addition to being vulnerable to the regular economic forces which influence a building's survival, such as inflation, interest rates, and spatial supply and demand factors, landmarks encounter an extra set of problems because of their frequently unusual design. Architecturally noteworthy structures, constructed with aesthetic considerations rather than the requisites of economic efficiency in mind, often house great halls, corridors, and meeting areas. Few firms, at present, are willing to contribute to the support of these extraordinary spaces by paying higher rents; as such, the design of landmark buildings has led, in many cases, to an increase in their underutilization and subsequent deterioration. Size, too, plays an important role in the life of a building. 
Landmarks are generally smaller in bulk than modern structures and often do not fulfill the maximum development potential of their site as allowed under New York City's Zoning Resolution. In a good market, owners of landmarks are encouraged to raze their structures and replace them with buildings which promise a higher economic return.

In soft markets, when the supply of space is greater than the demand for space, buildings with high vacancy rates are frequently demolished as a means of reducing taxes. In New York City, "taxpayers", which are small quonset hut structures housing discount merchandise and convenience stores and which yield some income, are erected on sites which formerly contained money-losing buildings. The property tax structure is an important factor which does not promote landmarks preservation; for the most part, the tax system favors either new construction or no building, rather than rehabilitation or re-use. 1

\section{B. The State of Real Estate in New York City}

New York City is an urban center which has experienced the exodus of the white collar worker population from the City to the suburbs. The influx of Latin Americans to the City has served to retain its overall population level, for the most part; but this group, comprised of unskilled workers who speak foreign languages, to a large extent, has been unable to secure work in the City. New York's blue collar unemployment rate and welfare rolls are among the largest in the country, while the City's suburbs are among the most affluent.

Business and industry have also relocated to New York City's surrounding areas. Since 1960 , the City has lost over 50,000 jobs in the

${ }^{1}$ See Joe A. Shull, "How to Use the Tax System to Promote Historic Preservation," Real Estate Law Journal 398 (1976). 
wholesale and retail industries, over 260,000 jobs in the manufacturing industry, and over 40,000 white collar jobs. Although the government's role as an employer increased by $38 \%$ in this period, the City's fiscal crisis is sure to curtail this source of jobs in the next years. ${ }^{2}$ In spite of the evident indications of the City's future social and economic instability, new building and extensive investment in real estate occurred at an extraordinary pace during the Sixties. Since 1965, 80 million square feet of office space were added to the $150 \mathrm{million}$ square feet already standing in Manhattan alone. ${ }^{3}$ In Lower Manhattan, the City's oldest district located south of Chambers Street, 35 million square feet of office space were constructed between 1965 and 1970, only to be followed by the building of the almost $9 \mathrm{million}$ square feet World Trade Center. 4

Among the results of this new building and the concurrent structural changes in the City are a present office space vacancy rate of $18 \%$ in Manhattan and billions of dollars in dead capital. 5 Lower Manhattan's vacancy rate is estimated at $11 \%$ or over $10.5 \mathrm{million}$ square feet of office space. ${ }^{6}$ Even with rents averaging $\$ 5-6 /$ square foot less in Lower Manhattan, major tenants continue to move from the older buildings in the financial district to Midtown Manhattan, Westchester County, or New Jersey.

\section{Allan B. Talbot, "City's Top Planners Trapped in the Past,"} New York Times, December 28, 1975, Section 8, p. 1.

3 Eleanore Carruth, "The Skyscraper Losses in Manhattan Office Buildings," Fortune, February 1975, p. 79.

"Shirley L. Benzer, "Downtown, It's a Tenants' Market," Times, August 11, 1974.

${ }^{5}$ Carruth, op. cit.

6 Benzer, op. cit. 
While the office market is stronger in Midtown Manhattan, this area is not without its white elephants and financial disasters: Tishman Realty Corporation has already lost $\$ 23$ million dollars on the recently constructed 1166 Avenue of the Americas ( $1.4 \mathrm{million}$ square feet); Arlen Realty and Development has lost nearly $\$ 3$ million dollars on 1500 Broadway $(368,000$ square feet) built in 1970; Uris Buildings Corporation has suffered a default on a $\$ 62$ million dollar construction loan for 1633 Broadway (2,050,000 square feet); the landmark Chrysler Building (850,000 square feet) on 42 nd Street, with $\$ 42$ million dollars in mortgages coming due this year, has been the subject of a foreclosure suit against its owner, Avon Associates, of which Sol Goldman is a principal. 7

Manhattan's loft buildings have also suffered from industrial relocations. In 1975, 25 foreclosure suits were initiated as compared to 9 in 1970. "The listings of six Manhattan real estate firms uncovered 4.1 million square feet of vacancies... $31 \%$ of the rentable space in the factories, lofts and industrial buildings involved." 8

The housing situation in New York City is becoming increasingly worse; in spite of a $2.8 \%$ vacancy rate 9 in the City. overall, 50,000 abandoned, apartments per year are being replaced by less than 10,000 new or rehabilitated units annually. ${ }^{10}$ The contributing factors to this situation

7Data obtained from Carruth, supra note 3, and Alan S. Oser, "Chrysler Building Facing Test," New York Times, October 15, 1975.

${ }^{8}$ Alan S. Oser, "Zoning Revisions to Expand Loft Conversions Are Urged by New York Real Estate Board," New York Times, October 29, 1975, p. 69.

9Joseph P. Fried, "Apartment Vacancy Rate is Placed at $2.8 \%$ in City," New York Times, November 13, 1975.

10 Maurice S. Paprin, President, Associated Builders and Owners of Greater New York, Inc., in Letter to Editor of the New York Times, August $17,1975$. 
are a $200 \%$ rise in fuel costs in the past two years, an $11 \%$ rise in this year's property tax $(\$ 8.187 / \$ 100$ assessed valuation, a decline in the market value of apartment houses to as much as $50 \%$ in some cases, 11 and an up to $70 \%$ rise in construction costs since 1967 , occurring mostly since $1971-72.12$

The picture for real estate in New York City is grim indeed, and a recovery is not expected for at least ten years, if at all. The need for additional office and industrial space no longer exists and the direct costs of housing maintenance have made rehabilitation and new construction under the current laws, in spite of the need for apartments, economically unsound undertakings.

In addition to the imbalances in the local real estate market and the City's socio-economic structure, a most fatal blow to investment in property was delivered by the credit crunch of the past two years. In September, 1974, the prime lending rate reached $10.38 \% ;^{13}$ the availability of mortgage money and interim financing were so low and the price of such funds so high in this period that savings and loan institutions, real estate investment trusts, and the construction industry are crippled today, even with the recent easing of these conditions.

One might expect that with the private sector's inability to provide sufficient investment in the City's built environment, the government would come to the rescue in some way. However, the federal government's

${ }^{11}$ Charles Kaiser, "Prices of Buildings in Manhattan Falling Sharply," New York Times, October 28, 1975, Section 8, p. 1 .

${ }^{12}$ Economist Intelligence Unit Ltd. Report: The U.S. Property Market (London, June 1975), p. 12. (The property tax in New York City in 1976 is now $\$ 8.795 / \$ 100$ assessed valuation.)

13 Ibid. 
community development program, which is based upon complicated revenue sharing formulas which do not favor urban centers, is inadequate in providing the funds necessary to meet New York City's housing needs. The Section 8 program, which is aimed at supplying financial incentives to private developers, is considered by most to be too complicated and, in the end, too unproductive, to undertake.

The main thrust of the Federal effort has been to sweep the realities under the rug. The objective of the 1974 Community Development Act was to set the Government out of the business of building housing, and the rent-subsidy program, while it has much to recommend it in principle, was really meant as a way of passing the problem of production back to the private sector. This effort, too, has become almost academic, because the involvement the Government was trying to escape--entrapment in inflationary construction and the mismanagement of programs and other long-term ills-- is proving to be even less attractive to private investors. Cities everywhere are finding that financing for rehabilitation, one of the prime objectives of the $1974 \mathrm{Act}$, is as unobtainable as that for new housing starts. ${ }^{14}$

It is unlikely that the financially troubled State of New York will be of direct assistance in revitalizing New York City. Of the Stateinitiated organizations, the Urban Development Corporation has collapsed, and the Battery Park City Authority and the Housing Finance Agency cannot easily obtain financing.

The City's Municipal Loan Program, which offers money at $7 \%$, has dried up; in any case, the city is no longer in a position to supply money to any individual or institution, at this time. The tax structure of the City does not particularly encourage renovation or preservation, with two exceptions: the $\mathrm{J} 51$ Program, ${ }^{15}$ a tax incentive for converting

${ }^{14}$ Ada Louise Huxtable, "The Housing Crisis," New York Times, November 18,1975 , p. 37 .

${ }^{15}$ New York City Administrative Code Section J51-2.5. Currently there are a number of proposals underway which will expand this program to include many types of residential units, as well as commercial properties. 
loft buildings to residential uses, and the tax abatements permitted, although never issued, for landmark owners. The best bets for landlords currently are to retain unimproved property as is or to demolish moneylosing buildings. The latter was the case with the recently destroyed Cities Services buildings in Lower Manhattan: the company saves $\$ 280,000$ in taxes a year. 16

How, then, are landmark properties affected by the City's unfavorable real estate situation? It is clear that tenants are moving out of older buildings and that rental replacements do not exist, thereby weakening the cash-flow stability of many historic structures. In the absence of major tax boosts and subsidies, the costs of maintaining and modernizing landmarks can become prohibitive if the expenses of complying to the architectural standards prescribed by law are great. Banks and lending institutions are reluctant to refinance mortgages or offer renovation loans. The increased costs of fuel and maintenance have contributed to the disuse of many religious and institutionally owned landmarks. The City's financial crisis, spurring staff cutbacks and lessening service levels, has left many fine public buildings underutilized or vacant. These factors--the trends of the finance, real estate, and construction industries--pose the real and complex problems for landmarks preservation and necessitate practical and innovative solutions by those concerned with the physical shape and vitality of the City.

The remainder of this section will deal with two mechanisms which have been used to preserve landmark structures: air rights transfers and adaptive use proposals. Each considers the special architecture of the building and economic interests and legal rights of the landmark

${ }^{16}$ Ada Louise Huxtable, "What's Best for Business Can Ravage Cities," New York Times, Apri 1 6, 1975, Section 2, p. 30. 
owner. In spite of numerous successes, neither method is sufficient to ensure the preservation of most endangered landmarks.

\section{Development Rights Transfers}

The New York City Zoning Resolution, which was revised in 1961 , reflects the City's expectation of large-scale development and greatly increased growth. The central business districts in Manhattan, especially, were undergoing tremendous changes, and the competition for prime commercial development sites in the Midtown area was entering a peak period.

In addition to regulating land uses and population density, the Zoning Resolution establishes incentives to developers to provide for the public urban amenities such as open space, plazas, and arcades. This is accomplished by the assignment of a floor-area ratio (F.A.R.) for each district to fix the maximum bulk of a building. To compute the amount of allowable floor area for a structure, one multiplies the lot area by the F.A.R. For example, a zoning lot of 10,000 square feet in a district containing an F.A.R. of 15 would allow the construction of a building of 150,000 square feet. This bulk formula, when combined with building codes, other zoning requirements, and possible bonuses for amenities, can yield up to $20 \%$ of usable space over the permitted F.A.R. and is considered to be an effective density control technique. The operative premise is that a developer can obtain additional rentable space in a structure by providing benefits to the public within the limitations of the zoning ordinance; in this way, the developer is compensated in an amount equal to or over the cost of the non-income producing space which is designated for public use.

The results of New York City's incentive zoning are varied. In some 
cases, attractive plazas and parks were created, enlivening areas which would otherwise be desolate. In other cases, tall, skinny buildings rise above poorly landscaped public spaces which go unused year round. Architects then blame city planners for limiting design choices and city planners, in turn, blame developers for devising building programs which reflect only economic goals. 17

The F.A.R. concept is utilized in another manner. The Zoning Resolution allows that the unused portion of the permitted F.A.R. of a building can be transferred to contiguous sites held in common ownership. That is, if the bulk of a structure in a district with an F.A.R. of 15 amounts to only 12 , then an F.A.R. of 3 can be added to a contiguous building or can increase the development potential of a vacant lot by 3 , provided that the ownership is the same for both sites. These restrictions of location and ownership are mandated for the purposes of controlling density and preventing an accumulation of air rights or development rights by a single owner or developer. Air rights are most valuable when there is a high level of construction activity in an area, such as Manhattan, which is welldeveloped and which contains little space in which to build.

The technique of air rights transfers is particularly applicable to landmark buildings; structures built over 40 years ago tend to be significantly smaller than more modern buildings and hence usually do not fulfill the entire allowable F.A.R. of their sites.

In 1968, a provision in the Zoning Resolution was adopted to allow the unused air rights on landmark sites to be transferred to non-contiguous or adjacent lots in common ownership. ${ }^{18}$ Adjacent was defined as a

17 For an interesting discussion of this topic see Jonathan Barnett, Hrban Design as Public Policy (New York: McGraw-Hil1, 1974).

${ }^{18}$ New York City Zoning Resolution $\S \S 74-79,792$, and 793. 
lot across the street or intersection. 19 However, the amount of transferred F.A.R. was not permitted to exceed the allowable F.A.R. on the receiving lot by more than $20 \%$.

The City passed further relaxations regarding transfers of development rights from landmark building sites in 1969. Adjacent is defined

as:

A lot which is contiguous to the lot occupied by the landmark building or one which is across a street and opposite to the lot occupied by the landmark building, or, in the case of a corner lot, one which fronts on the same street intersection as the lot occupied by the landmark building; it shall also mean in the case of lots located in C5-3, C5-5, C6-6, C6-7 or C6-9 (commercial use) districts a lot contiguous or one which is across a street and opposite to another lot or lots which except for the intervention of streets or street intersections form a series extending to the lot occupied by the landmark building. 20

Requests for transfers of air rights require the approval of the

City Planning Commission and must include:

A site plan of the landmark lot and the adjacent lot including plans for all development on the adjacent lot; a program for continuing maintenance of the landmark; and such other information as may be required by the City Planning Commission. The application shall be accompanied by a report from the Landmarks Preservation Commission. 21

The Planning Commission's approval of the transfer plan is the granting of a special permit which is based upon the meeting of certain conditions by the applicant. The Commission must find: 1) that the transfer will not result in extensive density or land use changes which will harm the occupants of the surrounding area; 2) that the maintenance program will

19 Norman Marcus, "Air Rights Transfers in New York City", Law and ontemporary Problems, Summer 1971, p. 374.

${ }^{20}$ N.Y.C. Zoning Resolution $\$ 74-79$ (parenthesis mine). In addition, the allowable amount of bulk transferred from landmark $s$ ites to commercial lots is unrestricted, \$74-792.3.

${ }^{21}$ N.Y.C. Zoning Resolution, \$74-791. 
assist in preserving the landmark; and 3) that transfers of air rights from publicly-owned buildings will be contingent upon the provision of some pedestrian or transportation improvement. 22

In the late Sixties, the technique of air rights transfers was viewed as being an especially useful tool for preserving landmark builddemolition of economically undesirable buildings, such as landmarks, and their replacement. The use of air rights transfers, theoretically, would enable the landmark property to increase in value in accordance with the market value of surrounding buildings. Importantly, the sale of the development rights would ensure the preservation of the landmark and compensate the property owner at the same time. While the actual value of air rights has now been brought into question, 23 the transfer mechanism in principle was heralded as an effective means for resolving regulatory conflicts.

${ }^{22}$ N.Y.C. Zoning Resolution, $\$ 74-792$.

23 In the case of Newport Associates, Inc. v. Solon, plaintiff was the owner of land and a building with less bulk than allowed by New York City's Zoning Resolution; the defendant was the lessee of the building and owner of two adjacent parcels. Plaintiff argued that the transfer of the development rights from one of defendant's lots to another for the construction of an office tower would decrease the value of his property. The court held for the defendant. 30 N.Y. 2nd 263, 283 N.E. 2nd 600, 332 N.Y.S. 2nd 617 (1972); cert. denied, 410 U.S. 931 (1973).

According to Norman Marcus, this case was significant because "it shows that the court of appeals was comfortable with the notion that development rights from the land that generates them, have a value of their Own and can be transferred easily." "Mandatory Development Rights Transfers and the Taking Clause: The Case of Manhattan's Tudor City Parks," Buffalo Law Review, Fall 1974, 24:91.

However, the value of development rights has been recently challenged in Fred F. French Investing Co., Inc. V. City of New York. In this complicated case, the City down-zoned an area in Manhattan known as Tudor City Parks and required that the private owners preserve and maintain a park for public use. The City's compensation for the owners' undertaking consisted of allowing the transfer of air rights over the park to other areas of the City. The lower court held that the rezoning constituted a taking, that the unsold development rights was not just compensation, and 
The use of air rights transfers in New York City has helped to preserve two historic areas. The first is Amster Yard on Manhattan's upper East side, a pocket of small residential and commercial structures and a garden. The owner of Amster Yard and the developer of the commercial site to which the unused air rights from Amster Yard were to be transferred established a $\$ 100,000$ trust fund to ensure the maintenance of the landmark buildings.

At New York City's South Street Seaport, an urban renewal plan was enacted which provided for a redevelopment area and a preservation area. After the addition of a new finding by the City Planning Commission to the Zoning Resolution which permitted the Commission to waive certain air and light requirements, air rights were permitted to be transferred from the preservation area to the redevelopment area. ${ }^{24}$ A consortium of banks then bought the air rights in the Seaport.

Neither the Amster Yard nor the Seaport transfer plans has been fully implemented because of the glutting of the office market, which makes construction of additional commercial space economically imprudent. The receiving site adjacent to Amster. Yard has yet to be developed and the banks still hold the air rights in the Seaport district. While the development plans have not been carried out, both air rights schemes contributed to saving the historic buildings.

For the most part, the transfer of development rights mechanism is currently viewed as only a potentially effective tool for landmarks preservation.

Among the problems in using the transfer technique is the issue of

that no relief from declaring the zoning ordinance invalid was warranted. 352 N.Y. 2d 762; Affirmed, New York Law Journal, May 25, 1976. 24 Marcus, op. cit., p. 377. 
what constitutes an appropriate transfer site for development rights. The City's proposal to transfer Grand Central's unused air rights to the adjacent Biltmore Hotel site was deemed unacceptable in the dissenting opinion of the court because it required the demolition of a profitmaking entity or resulted in the occupancy of that lot of a 103-story building. 25 If adequate transfer sites for a landmark's air rights are not available, can and should other provisions for disposing of the lot's development potential be singly legislated? The Fred French case cited herein ${ }^{26}$ clearly establishes this as a problem in the transfer approach.

Most importantly, the effectiveness of the air rights transfer technique is dependent upon market supply and demand forces. While it is likely that many landmarks will be threatened with deterioration and loss in the near future, the lack of real estate investment--buyers of air rights--makes this tool presently unworkable in New York City.

What is needed, perhaps, for increasing the usefulness of the development rights transfer technique in the city is a restructuring of the present statutory scheme. But can a city-wịde plan for development rights transfers be formulated to accomplish the following ends: a) rely less on market factors for implementation; b) maintain density and urban design standards of areas; and c) diminish the windfall-wipeout tendencies of transferring development rights?

\section{Adaptive Uses of Landmarks}

For many years, the term "preservation" was synonymous with

${ }^{25}$ See Chapter 11 , discussion of Penn Central Transportation ComLet al.v. City of New York.

${ }^{26}$ See footnote 23 . 
"restoration": the reconstruction of the building to its original appearance.

In cases where the structure has undergone few alterations or has a full set of architectural plans in existence, restoration is possible and the work frequently results in an authentic representation of the architecture of some past era. Many restored buildings continue to be used for the same purposes for which they were built, such as residences, and a significant number have been converted to small self-supporting museums.

Large-scale restorations of entire towns or districts, such as Stockbridge, Massachusetts, and Jacksonville, Oregon, have been successfully undertaken. The great concentration of cultural and historic amenities which are present in restored villages provide these towns with sufficient drawing power to enable them to maintain their economic stability.

In urban centers, however, individually restored houses and museums are often burdened with financial difficulties which threaten their survival. The extensive cultural resources of American cities--the Chicago Art Institute, the Metropolitan Museum of Art in New York, the Fine-Arts Museum in San Francisco, to mention a few--present small museums with strong competition in terms of visitations and financial support. New York City, especially, is faced with massive cutbacks in the budgets of its major cultural institutions, and visitors' saturation point for cultural centers and museums in New York $\mathrm{C} i$ ty was reached long ago.

With the realizations that not every architecturally significant structure can be restored in a technical sense and that restoration work by itself does not guarantee the survival of an historic structure in the future, the historic preservation movement turned to the development of adaptive uses for seriously endangered landmarks.

Adaptive use of landmark structures is generally defined as the 
conversion of a building to an economically viable use while retaining those aspects of the structure which are architecutrally or historically noteworthy. There are two major differences between the adaptive use of landmarks and the renovation of typical buildings;

(1) Process--The development of an adaptive use proposal normally entails feasibility studies and market analyses which evaluate alternate plans for the structure's conversion. In most cases, where new uses for old buildings are sought, the use for which the structure was intended is no longer suitable. Examples of such buildings are churches, railroad stations, courthouses, and certain types of public buildings. A case-by-case approach is necessary to adaptively use buildings which were constructed to fulfill a particular function; locational, physical design, economic, and a wide range of other variables must be assessed to determine the structure's most practical modern-day use. The formulation of adaptive use proposals for landmarks requires greater amounts of planning and development expenses than typical building renovation projects.

(2) Technical Transformation of the Building--The implementation of a re-use plan for a landmark building will often involve architectural and construction constraints which are more costly than those for a typical renovation. While no attempt may be made to restore the structure, preservation architects do try to keep, to the greatest extent possible, the original fabric and ornamental features of the building. At times, the use of additional consultants, outmoded materials, and extraordinary demolition and construction methods is required to preserve the architectural integrity of a building. Additionally, a change 
in the use of the building may precipitate more substantial problems in meeting building, fire, and safety codes, as well as in complying with the zoning ordinance.

The recycling of old buildings has taken place across the country. Ghirodelli Square in San Francisco is, perhaps, one of the most widely known examples of adaptive use. Though not a landmark, this complex of specialty shops, restaurants, and plaza areas occupying a former warehouse is considered to be a highly successful design and economic undertaking. The 0ld St. Louis Post Office, built in 1884, was renovated to become a hotel/shopping center while its French Second Empire design was preserved. The 0ld Federal Court Building in St. Paul, Minnesota, a Romanesque Revival building constructed in 1892 , is now a city educational and cultural center. In the 1830's Custom House Block on Long Wharf in Boston, warehouses were converted to restaurants and apartments.

A number of New York City's landmarks have been converted to new uses. Among them are the Jefferson Library in Greenwich Village, formerly a market; the New York Shakespeare Festival Theater, originally a library; and the Bouwerie Lane Theater, previously a bank.

A number of factors now encourage building conversions, rather than reconstruction. In addition to decreased labor and construction costs, significant savings can be gained from the elimination of demolition work, the recycling of materials, and the shorter duration of time needed for work. It is estimated that the cost of renovating an apartment is $\$ 15,000$ to $\$ 20,000$ less than the cost of a new building unit. 27

In spite of the many economic advantages in reusing old buildings, there has not been a proliferation of successful adaptive use projects

27 Alan S. Oser, "Hope for Renovation Surge Pointed on 'J51'," New York Times, November 14, 1975, p. 60. 
for endangered landmarks in New York City. The two major impediments to implementing re-use plans are the limited availability of financial resources for preservation, construction, and operating expenses, and the opposition of the owner of the structure to cooperate in what is, in many cases, a civic-minded venture.

The difficulties in reusing old buildings can best be illustrated by a project now underway at the New York Landmarks Conservancy. The Conservancy is a private, not-for-profit organization which was established in 1973 for the purposes of owning and managing buildings of architectural importance throughout the State of New York. The primary objective of the Conservancy is to develop and implement adaptive use proposals for structures as a means for saving landmark quality buildings. Since its incorporation, the Conservancy has expanded its activities to include neighborhood conservation, planning, and advocacy projects in New York City.

The Conservancy's premier project was the United States Custom House at Bowling Green. The Custom House is an important example of the Beaux Arts style of architecture, designed by Cass. Gilbert and completed in 1907. A federal and city landmark, the Custom House contains a wide variety of types and colors of marble within its public spaces, a series of Reginald Marsh murals in the glass-domed rotunda, and, in front of its northern facade, four statues which represent the continents and which were sculpted by Daniel Chester French. When the Customs Service, in the late 1960's, announced plans to relocate its functions from the Custom House to the World Trade Center, the downtown community voiced considerable interest in preserving and reusing the Custom House.

To this end, the Custom House Institute, an informally constituted 
group of businessmen and politicians, ${ }^{28}$ sponsored a feasibility study to determine appropriate new uses for the Custom House. The project was funded by contributions from the downtown business community and carried out at cost by a team of consultants which included 1.M. Pei \& Partners, Cushman $\&$ Wakefield, and HRH Construction. Working with the Mayor's office of Lower Manhattan Development (OLMD) and the Conservancy, the consultants completed the study in 1974; it was recommended that the Custom House, which contains over 500,000 square feet, be renovated to house a mixture of commercial and institutional uses. The basement and portions of the first two floors of the Custom House, including the intricately designed spaces, were reserved for cultural uses and would not require the splitting up of these areas. The upper six stories, previously used as office space, were to be modernized. This combination of uses was deemed economically viable, for the consultants determined that the high commercial rents could be used to offset the lower institutional revenues. As such, the re-use plan for the Custom House also provided an innovative means of funding for the arts. The cost of the conversion was estimated at $\$ 25,000,000$.

The re-use plan for the Custom House was made possible by an amendment, in 1972, to the Federal Surplus Property Act. 29 This law authorizes the General Services Administration (GSA) to transfer surplus federallyowned properties of historic value at no consideration to other governmental units, provided that an acceptable plan for the building's preservation and re-use is presented to the GSA. The legislation permits the

${ }^{28}$ The Committee of Sponsors, now headed by James D. Wolfensohn, President of the J. Henry Schroder Banking Corporation, includes such notables as Whitney North Seymour, Sr., David Rockefeller, John V. Lindsay, John Loeb, Cyrus Vance, Gustave Levy, and Hoyd Ammidon.

${ }^{29}$ P.L. $92-362$. 
building to be put to revenue-producing uses, but mandates that all net revenues be utilized for "public park, recreation or historic preservation purposes."

The federal government's new property disposal procedure for historic buildings encouraged the Office of Lower Manhattan Development to propose state enabling legislation which permits the city to lease the Custom House at a nominal fee and without public bidding to a not-for-profit development organization. The newly formed Landmarks Conservancy was considered to be an appropriate entity for such receivership and was asked to coordinate the implementation phase of the study and to prepare itself for the eventual custody of the Custom House.

The implementation phase of the feasibility study, which is currently underway, consists of the following tasks:

(1) the refinement of the conclusions of the study;

(2) the identification and securing of a major tenant or tenants for the Custom House;

(3) the processing of the applications and agreements for the transfer of the Custom House from the federal government to the City, and from the City to the Conservancy.

The change in New York City's mayor in 1974 shifted the coordination of the Custom House project from the Mayor's Office of Lower Manhattan Development (OLMD) to the Conservancy. Richard Weinstein, the director of OLMD under the previous Lindsay Administration, became the project director on a paid consultant basis, and the Conservancy, working with Weinstein, the real estate and design specialists who prepared the feasibility study, and the sponsors of the Custom House Institute, is carrying out the work which will culminate in the renovation of the building.

In spite of the extensive amount of public and private cooperation 
throughout the history of this project, many obstacles exist to its successful completion. Most importantly, the extremely high office vacancy rate in Lower Manhattan--10,500,000 square feet are unrented--militates against the creation of additional office space in the Custom House. In the past year, reduced renovation plans and new schemes involving different uses for the building have been devised, but even the most minimal plan will cost millions of dollars. The securing of a major tenant to ensure an income return large enough to amortize the financing and construction costs of the conversion has been unsuccessful thus far, and there are no encouraging indications that this will occur in the near future.

Several adaptive use problems can be highlighted by the Custom House project. The costs of reusing an older building of this genre--large, with unusually designed spaces--are much greater than a more simple structure, such as a warehouse. Expensive precautions are necessary in order not to disturb the architectural unity of the building, i.e., carefully maintaining unrentable spaces. Since the Custom House is a federallyowned property which has been exempt from city zoning regulations and fire and safety codes for 70 years, its renovation requires extensive work and great expense to meet modern building regulations. Finally, the prospects of obtaining a tenant for the building are dependent on the real estate market and the City's economic development policies which, at the present time, offer few incentives for businesses to remain in New York.

\section{E. Conclusions}

1. The Design of 0ld Buildings

a. The small size and ornate and unusual public spaces of 
landmark buildings often limit the amount of income which can be generated from the use of the structure. The replacement, then, of landmark buildings with higher profitmaking structures is a preferred activity in a competitive market and is a continuing threat to landmarks in developing areas.

b. The obsolescence of historic properties also contributes to their jeopardy. Outmoded mechanical and climate control systems increase the operating expenses--usually passed along to the tenants--of the structure and prompt the underutilization and deterioration of the landmark.

c. While the age and architecture of a landmark are not always significant factors to consider in warehouse and brownstone conversions, they figure greatly in the renovation costs for more elaborately designed buildings. Conformance with modern building and housing codes in reusing landmarks can be a steep expense which hampers the successful completion of a project.

\section{Real Estate Factors}

a. Taxation policies often present great impediments to preserving landmarks. For example, the tax structure encourages new construction rather than renovation work by offering different tax-deductible rates of depreciation. In some cases, even with greater costs for labor and materials in new construction, it may still be more financially rewarding to demolish the landmark and build anew. In the event that the landmark is losing a great amount of money, it may be more prudent for an owner to raze the 
existing building if only to decrease the property taxes on the lot.

b. In New York City, as in most older urban areas, general real estate factors exist which are adverse to preserving landmarks: high vacancy rates in commercial and industrial buildings and limited amounts of funds from the public and private sectors for rehabilitation work. The real estate and construction industries and lending institutions have yet to recognize preservation as a possible key to revitalizing neighborhoods and securing their respective interests in the city.

3. The Lack of Practical Techniques for Saving Landmark Buildings Presently, the most highly regarded means for preserving older buildings--transfers of unused development rights and adaptive use--are extremely dependent upon market forces and limited in application to few cases. 


\section{CHAPTER II: THE LEGAL FRAMEWORK FOR LANDMARKS PRESERVATION IN NEW YORK CITY}

\section{A. Foderal Involvement in Historic Preservation}

In most respects, the federal government's role in historic preservation has been minimal and is not expected to increase in the near future. While the federal government has been, perhaps, a leader in stating the need for historic preservation as a matter of policy and a number of national laws contain sections which favorably deal with historic preservation, a direct commitment to saving landmarks is clearly lacking.

In 1889, a four-story tower constructed over six centuries ago by the Hohokam Indians called Casa Grande in Gila Valley, Arizona, was officially designated ${ }^{1}$ as the first national landmark. A few years later, in 1896, the U.S. Supreme Court upheld the constitutionality of the government's power to preserve landmarks in a case which involved the construction of a railroad across the historic Gettysburg battlefield. The Court pointed to the ability of the monument to enhance "the respect and love of the citizen for the institutions of his country" and to strengthen "his motives to defend them" 2 as being in the public interest.

The Antiquities Act of $1906^{3}$ followed as the next important federal

INicholas A. Robinson, "Historic Preservation: The Qualities of the Man-made Envi ronment, " New York Law Journal, May 28, 1974. $(1896)^{2}$ United States v. Gettysburg Electric Ry. Co., 160 U.S. 668,681

334 Stat. 225 as amended, 16 U.S.C. $\$ \$ 431-433$ (1970). 
action in historic preservation, authorizing the President to establish monuments on government-owned lands. However, it was not until the 1930's that the federal government's involvement in historic preservation broadened.

In 1933, the Historic American Buildings Survey (HABS), still in existence today, was established in the Department of the Interior. The staff of the HABS is responsible for the architectural and historic documentation of significant buildings across the nation. Inclusion in the HABS does little to protect historic properties, for "over a third of the 16,000 structures 1isted in the HABS are gone."14

The Historic Sites Act of $1935^{5}$ centralized historic preservation activities in the National Park Service. The Act declared "the preservation of historic sites, buildings and objects of national significance for the use, inspiration and benefit of the people of the United States to be a national policy. "6

Emulating England and many other countries, the National Trust for Historic Preservation was established 7 in 1949 to receive donations for the acquisition and maintenance of historic sites, buildings, etc. However, the Trust owns and maintains only twelve such properties across the nation today.

Finally, the National Historic Preservation Act of $1966^{8}$ established

4John J. Costonis, Space Adrift: Saving Urban Landmarks through he Chicago Plan (Urbana, I1linois: University of I1linois Press, 1974),

549 Stat. 666,16 U.S.C. $\$ \$ 461-7$.

6 lbid.

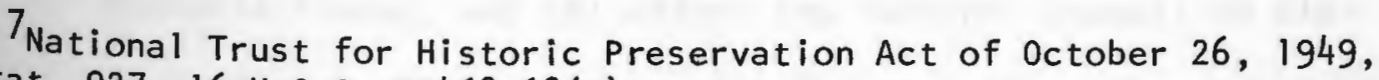
63 Stat. 927, 16 U.S.C. $\$ \$ 468-68(\mathrm{e})$.

8P.L. $89-665,15$ U.S.C. $\$ 470,36$ C.F.R. $\$ 800$ et seq. 
the present federal structure for historic preservation. The National Historic Preservation Act essentially contains three authorizations:

(1) That the Secretary of the Interior maintain a listing of historic districts, sites, structures, buildings, etc., known as the National Register of Historic Places;

(2) That a grants program to States be established to fund up to $50 \%$ of the costs of surveys and development projects;

(3) That an Advisory Council on Historic Preservation be created, composed of the Secretaries of the Interior, Housing and Urban Development, Commerce, and Treasury, the Administrator of the General Servises Administration, the Attorney General, and the Chairman of the National Trust for Historic Preservation. The Council is located within the National Park Service of the Department of the Interior and serves as an advisory agency to the President and Congress.

The role of the Advisory Council in local preservation matters is minimal, and the administration of the National Register and the grants program is left largely to designated State aggencies. While the final approval of Register listings and funding applications rests with the National Park Service, rarely is a state recommendation rejected.

Protection for historic properties is mandated in several laws:

(1) National Historic Preservation Act of 1966 (NHPA). Before approving funds or a license for a project, the agency head must (a) take into account the consequences of the action upon any historic property listed in the National Register of Historic Places, and (b) afford the Advisory Council on Historic Preservation adequate time for comment on the undertaking. 9

$9_{15}$ U.S.C. $470 f(1970)$. 
(2) Department of Transportation Act of 1966. This statute states that "the Secretary of Transportation shall not approve a program or project which requires the use of . . an historic site of national, state or local significance. . unless

(1) there is no feasible and prudent alternative ... (2)

such program includes all possible planning to minimize harm." 10

(3) Demonstration Cities and Metropolitan Development Act of 1966.

This law provides funds for historic surveys and preservation efforts. 11

(4) National Environmental Policy Act of 1969 (NEPA). NEPA includes historic preservation as a national environmental goal, ${ }^{12}$ enabling historic properties to be the subjects of agency reviews and environmental impact statements required by the Act. ${ }^{13}$

(5) Executive Order $\# 11593$ of May 15,1971 . This action requires that "agencies of the executive branch of the Government shall . . in consultation with the Advisory Council on Historic Preservation, institute procedures to assure that Federal plans and programs contribute to the preservation and enhancement of non-federally-owned'sites, structures and objects of historical, architectural or archeological significance."114

These laws constitute the framework for review by public agencies of their actions to determine how federal involvement--1icensing and funding--

$10_{49}$ U.S.C. $\$ 1653(b)(1970)$.

$11_{40}$ U.S.C. $\$ 461$ (b) (1970).

1242 U.S.C. $\$ 3331$ (b) (4).

1342 U.S.C. $\$ 4332$.

1436 Fed. Reg. 8921. 
affects the preservation and protection of the architectural historic, and cultural environment. In spite of federal statutory directives to this end, "historic preservation in the man-made environment can expect little except aid and comfort from administrative federal sources. Commitment and action necessarily occur at the state and local plane."15

The first historic preservation case initiated under these federal laws involved the Westchester County Courthouse, which was scheduled for demolition as part of an urban renewal plan. In Save the Courthouse Comwee v. Lynn, et al., 16 plaintiffs sought a preliminary injunction to prevent the razing of the courthouse, a National Register property, claiming violations of the NHPA, NEPA, Executive Order 11593, and various regulations. Broadly defining HUD's duties in the project, the Court found that :

(1) HUD did not comply with regulations promulgated under NHPA, mandating that agencies identify properties "that are included in or eligible for inclusion in the National Register ${ }^{117}$ and once having identified such properties, determine whether the agency action has an effect upon the property. 18

(2) HUD's "threshold" determination (whether there is a "major federal action" and whether this action "significantly" affects the environment) was "both substantively and procedurally defective." 19

${ }^{15}$ Robinson, op. cit., p.2. March ${ }^{16}$ Save the Courthouse Committee v. Lynn, et al. (U.S.D.C., S.D.N.Y.,

1736 C.F.R. $\$ 800.4$.

1836 C.F.R. $\$ 800 \cdot 4(b)$.

${ }^{19}$ Save the Courthouse Committee v. Lynn, et al., p. 42. 
(3)

'HUD, in making its 'threshold determination', has wholly

failed to give sufficient and appropriate study to possible al ternatives. $" 20$

(4) HUD did not afford the public adequate time for comment.

The court then ordered the issuance of a preliminary injunction barring the defendants from proceeding with the demolition of the Courthouse. Shortly thereafter, the parties agreed to adopt a stipulation of settlement which, among other requirements, called for the filing of a case report by HUD, including an analysis of possible alternatives for the Cour thouse.

Recently completed by the firm of James D. Landauer Associates, the feasibility study concluded that no economic re-use alternatives exist for saving the Courthouse. ${ }^{21}$ The study currently is the subject of public hearings. Should HUD, after receiving the recommendations of the Advisory Council on Historic Preservation, decide to demolish the Courthouse, the Save the Courthouse Committee may then seek a reversal of HUD's decision on the grounds that it was "arbitrary and capricious."

As illustrated by this case and others which were subsequently brought to court, ${ }^{22}$ preservationists must vigilantly monitor federal agency activities if the purposes of the laws for protecting historic properties are to be accomplished. These laws provide the tools and bases for public

$$
20 \text { Id. at } 46 .
$$

${ }^{21}$ Carter Horsely, "On Trial: The Courthouse," New York Times, July 25, 1976, Section 8, pp. 1 and 8 .

22

The State Historical Society of Colorado v. Board of County Commissioners of El Paso County, et al., Civil Action No. 75-A-656 (United tes District Court for the District of Colorado), Stipulation and Agreement for Dismissal executed on June 26, 1975; see al so Honorable Charles

1540 al. v. The Association Residence Nursing Home, Inc., et al, wTthout prejudice before it reached the court. 
actions for preserving national landmarks and, in all likelihood, will not be implemented or enforced without citizen instigation.

B.

\section{te Involvement in Historic Preservation}

Historic preservation at the state level in New York is a function located in the Office of Parks and Recreation (OPR). The State Division of Historic Preservation within OPR is the designated state agency empowered by the U.S. Department of Interior to administer the federal grants program and the National Register nomination procedures. The Division received appropriations from both the federal and state governments for studies and the restoration and preservation costs of National Register properties. An applicant may receive up to a 50/50 matching grant for a project. In the past year, the state had a total of $\$ 800,000$ available for project development costs--an insubstantial amount to meet the preservation needs of New York State. 23

A State Historic Trust was established in $1966^{24}$ to acquire, operate, and maintain historic properties and to make studies and recommendations. The State Trust possesses thirty-five historic sites to date.

In 1956, New York State passed enabling ${ }^{25}$ legislation which gives cities and towns, at their option,

the authority to provide by planning or zoning laws for the protection of sites, buildings and works of art having a special or historical or aesthetic value, including reasonable control of the use of appearance of neighboring private property within public view. The power of eminent domain is conferred; also limitation or

${ }^{23}$ Meeting with Robert Pierpont, Restoration Architect for the State Division of Historic Preservation.

${ }^{24}$ Mckinney's Consolidated Laws of New York, Book 10, Sections 829-

${ }^{25}$ N.Y. Gen. Munic. Law $\S 96-a$ (Mckinney Supp. 1974). 
remission of taxes. 26

There are two pieces of state legislation which have yet to become effective and which may influence historic preservation activities. The first is the recently passed "baby" NEPA, which includes historic sites as a subject for environmental assessments. The draft guidelines are now in the review stage and are in need of more specific language with regard to historic properties. 27

The other is proposed legislation giving the localities the power to transfer unused air rights to other zoning lots. ${ }^{28}$ Because development rights transfers are often complex and entail many implications for community development, a bill was proposed with express authority and guidelines for the utilization of this technique by municipalities. Previously, development rights transfers were neither prohibited nor encouraged; the employment of this mechanism was left to the discretion of local governments.

\section{c. Landmarks Preservation in New York City}

The New York City Landmarks Preservation. Law ${ }^{29}$ was enacted in 1965 largely in response to the building boom of the late 50 's and early 60 's. During that time, many of the older buildings in the central business districts of the City--Midtown and Lower Manhattan--were razed and replaced by the towering skyscrapers that so characterize New York today.

26 Jacob H. Morrison, Supplement to Historic Preservation Law (New Orleans, La., April 5, 1972).

${ }^{27}$ State Environmental Quality Review Act, New York State Environmental Conservation Law, Article 8, part 617.

${ }^{28}$ Development rights transfers were discussed in detail in Chapter 1.

${ }^{29}$ New York City Charter and Administrative Code, Ch. 8A (1965), as amended, Local Laws of the City of New York, No. 71 (1973). 
The landmarks law establishes in the Parks, Recreation and Cultural Affairs Administration of the City an eleven-member commission which is comprised of three architects, an architectural historian, a realtor, a planner or landscape architect, and a representative from each of the five boroughs. The members of the Commission are appointed by the Mayor for staggered three-year terms. The Landmarks Preservation Commission is authorized to designate sites, districts, buildings, and structures which are found to be architecturally, historically, or culturally important as official city landmarks. This action encompasses only the exteriors of structures, except in cases where interior designations ${ }^{30}$ are sought. The approval of the Board of Estimate is needed for all designations recommended by the Commission. Procedures which regulate the appearance of designated landmark properties are set out in the ordinance; an owner must obtain a Certificate of Appropriateness or a Certificate of No Effect from the Commission before any alteration or demolition work is undertaken on his or her property. Fines and/or imprisonment are the consequences for persons who do not comply with this law.

Under the preservation law, the test for economic hardship for commercial property is the inability of the property to yield a return of at least $6 \%$ of its assessed valuation. If a landlord claims that the landmark structure cannot produce revenues above this amount, the law allows the Commission to reduce the real estate taxes on the property. 31 Should tax remission prove to be inadequate, the Commission has the right

${ }^{30}$ The Commission's power to designate the interiors of buildings was added to the City Charter in 1974, which accounts for the small number of interiors designated thus far.

$31^{\prime \prime T h e ~ p r o v i s i o n ~ f o r ~ c o m p e n s a t i o n ~ o f ~ o w n e r s ~ w h o s e ~ l a n d m a r k s ~ n e t ~ t h e m ~}$ less than $6 \%$ of the assessed value is based upon the amount allowed under the Rent Control Laws." Edward A. Wolf, "The Landmark Problem in New York", 22 hetramural Law Review of New York University 107. 
to seek another landlord for the property who proposes to utilize the structure in a manner consistent with the architectural integrity of the building. If all else fails, the City has the power to condemn the property.

To date, the Commission has designated over 450 individual structures and 27 historic districts, containing over 11,000 buildings, as city landmarks. The restrictions on individually designated landmark buildings and structures in historic districts are the same: the Commission must review and approve all proposed alteration and demolition plans.

The New York City Landmarks Preservation Law, combined with various provisions in the Zoning Resolution for transfers of development rights, 32 has been lauded for its innovation and practicability and has served as a model ordinance for localities across the country. However the law has recently been found defective both for not-for-profit owners and, perhaps, for corporate owners.

The first attack on the Landmarks Preservation Law came in 1966 in the Manhattan Club case. 33 The issues of the case concerned "substantive evidence" for the designation and the right of the State to place restrictions on private property for public purposes. The court upheld the landmarks law and affirmed its constitutionality.

The later Sailors' Snug Harbor case ${ }^{34}$ also supported the constitutionality of the Landmarks Preservation Law but questioned the reasonableness of its application. The petitioner, Trustees of Sailors' Snug Harbor,

32 New York City Zoning Resolution, §§74-790, 74-791, 74-792, 74-793.

33. Mtter of Manhattan Club v. Landmarks Preservation Commission, 51 Misc. $\frac{\text { tter of Manhattan Club v. Land }}{556,273 \text { N.Y.S. 2d } 848(1966) \text {. }}$

2d 376, 34 N.Y.S. 2d $314(1967)$. 
was

a tax-exempt, charitable institution established for the purposes of maintaining a home for retired seamen. Wanting to replace the landmark buildings with new structures to house the sailors, the Trustees sought exemption from the Landmarks Preservation Law to do so. Because the statute provided a standard for judging hardship for commercial properties anly, the court devised a critical test to determine whether the landmarks restriction on property owned by the Trustees constituted a "taking" without just compensation. 35 The criterion which the court established was whether the "maintenance of the landmark either physically or financially prevents or seriously interferes with the charitable purpose ${ }^{136}$ of the institution. To decide this point, the court devised three subsidiary questions:

(1) Whether the preservation of these buildings would seriously interfere with the use of the property,

(2) Whether the buildings are capable of conversion to a useful purpose wi thout excessive cost,

(3) Whether the cost of maintaining them without use would entail a serious expenditure. 37

Lacking sufficient information to answer these questions, the court remanded the case for further testimony. The case was never retried because the City of New York purchased the properties.

In 1974, in the Lutheran Church in America v. City of New York ${ }^{38}$

35 U.S. Constitution, Amendment V: "Nor shall private property be taken for public use without just compensation." New York State Constitution, Article 1, Section 7(a): "Private property shall not be taken for public use without just compensation."

3629 A.D. $2 d$ at 378,288 N.Y.S. at 316 .

37 Ibid.

38

35 N.Y. 2d 121, 316 N.E. 2d 305, 359 N.Y.S. $2 d 7$ (1974). 
case, the court utilized the test formulated in Sailors' Snug Harbor and found that the landmarks designation of the J.P. Morgan House was a compensable "taking" of private property. 39 The Morgan House had been used for a number of years as the headquarters for the Lutheran Church, a tax-exempt charitable institution. The Church, finding it necessary to expand, wanted to demolish the Morgan House and to construct a larger building on the site which would more adequately fulfill its spatial requirements. Similar to the Sailors' Snug Harbor case, plaintiff in the Lutheran Church case did not want to sell or lease the property, which would have given the Landmarks Preservation Commission the opportunity to secure a buyer or tenant; ${ }^{40}$ plaintiff successfully claimed that the Morgan House no longer satisfied its needs and "must be replaced if plaintiff is to be able freely and economically to use the premises.141

The dissenting opinion noted that the majority did not explore a number of important issues which should have affected the decision. ${ }^{42}$ Among these were the possibility of transferring the unused air rights over the Morgan House and the extent of hardship imposed on the owner as a result of the designation. "The Lutheran Church case raises a serious

${ }^{39}$ The Court found that the "Commission added the Morgan House to the resources of the City by the designation," using the doctrine of taking stated by Joseph Sax in "Takings and the Police Power" 74 Yale Law Journal 36 (1964). Mr. Sax later revised his theory in "Takings, Private Property and Public Rights," 81 Yale Law Journal 149 (1971): "The only appropriate question in determining whether or not compensation is due is whether an owner is being prohibited from making use of his land that has no conflict-creating spillover effects. If the answer is affirmative, compensation is due for the value of land for that use."

40 New York City Charter, Ch. $8 \mathrm{~A} \S 207-8.0$ (a) (2).

4135 N.Y. $2 d$ at 132316 N.E. $2 d$ at 312. 259 N.Y.S. $2 d$ at 17.

42 John J. Kerr, Jr., "Comment: Landmarks Preservation and Tax-Exempt Organizations: A Proposal in Response to Lutheran Church, 1 Columbia Journal of Environment Law 284, Spring 1975. 
question whether Sailors' Snug Harbor test was correctly applied.1143

However, it is clear that the adverse decision of the court in Lutheran Church has far-reaching consequences for landmarks preservation in New York City. Approximately one-third of the City's individually designated landmarks are owned by charitable institutions; it did not take long for one of them to use successfully the precedent of Lutheran Church. 44

After eight years, the present status of the Penn Central ${ }^{45}$ case favors preservation; another appeal, however, is expected and feared by the City. In 1968, Penn Central entered into a lease with UGP Properties for the development of an office tower over the landmark Grand Central Terminal, which Penn Central had owned and operated at a loss for a number of years. In subsequent months, three designs, prepared by the architectural firm of Marcel Breuer and Associates, were submitted to the Landmarks Preservation Commission as part of a request for a Certificate of Appropriateness; the final proposed plan, which called for the demolition of the terminal building to the ground level, was denied a Certificate of Appropriateness on August $26,1969.46$ Plaintiffs then sought to have the landmark de-designated in court.

4335 N.Y. $2 d$ at 133 N.2.; 316 N.E. 2d at 313 n.2.; 359 N.Y.S. 2d at 18 n.2. (dissent).

44 Mater of Society for Ethical Culture in the City of New York v. Spatt, New York Law Journal, December 24, 1975. Among other things, the court found "That the restrictions are not only a hardship but interfere with the religious, educational and charitable purposes of the plaintiff."

${ }^{45}$ Penn Central Transportation Company, The New York and Harlem Railroad Company, The 51 st Street Realty Corporation and UGP Properties, Inc. $v$. The City of New York and The Landmarks Preservation Commission of the Div of New York (Sup. Ct.), New York Law Journal, January 23, 1975; (App. Div.), New York Law Journal, December 18, 1975.

26, Landmarks Preservation Commission Report \#69005, 69006, August
1969. 
Because Penn Central is a partially tax-exempt corporation, further tax abatement under the Landmarks Preservation Law is not permitted. 47 In reaching its decision, the State Supreme Court relied on the constitutionality test for profit-making landmark properties formulated in the Sailors' Snug Harbor case:

Conceding the validity of regulation, the question presented is whether in the particular instance regulation goes so far that it amounts to a taking... If it does, it is constitutionally prohibited . . Chapter 8-A (Administrative Code of the City of New York) provides some guidelines as to what constitutes an undue burden on commercial realty and provides relief in such instances. . The criterion for commercial property is where the continuance of the lagdmark prevents the owner from obtaining an adequate return. 48

Finding "economic hardship, lack of compensatory alternatives to alleviate economic hardship, inadequacy of relief by tax rebate, etc.,"49 the trial court declared the Landmarks Preservation Law unconstitutional as applied.

In the Appellate Division case, the court concluded that Penn Central did not establish that plaintiffs (Penn Central, et al.) could not obtain a reasonable return from the terminal's operations because the submitted economic information "improperly attributed a considerable amount of railroad operating expenses (and some taxes) to their real estate operations" and because "plaintiffs have failed satisfactorily to show (a) an inability to increase the Terminal's income... or (b) that unused air rights over the terminal could not have been profitably transferred." 50 Finding that the property as a landmark could be

\footnotetext{
${ }^{47}$ New York City Administrative Code, Ch. 8-A, Sec. 207-8.0 a(2). ${ }^{48}$ Sailors' Snug Harbor, 49 App. Div. 2d at 378,288 N.Y.S. $2 d$ at 316. ${ }^{49}$ penn Central, N.Y.L.J., Jan. 23, 1975.

50 penn Central, N.Y.L.J., Dec. 18, 1975, p. 16.
} 
economically used, the Appellate Division reversed the decision of

the lower court.

D.

Problems of Preserving Landmark Structures

Why preserve architecturally, historically, culturally, or aesthetically noteworthy buildings? This question and its corollary--what is the place of architectural and artistic achievement, as well as history, in American society?--prompt answers which range from personal opinions to dollar figures for the benefits of landmarks preservation in cities. The most frequent responses are that historic preservation enhances the visual environment, that historic preservation contributes to the tourist trade of an area, and that historic preservation encourages a sense of community in neighborhoods.

Statutes at all levels of government assert these same general reasons for saving landmarks and declare that historic preservation is in the public's interest, and therefore warrants public regulation. Strict governmental protection of architectural and historic resources, however, has yet to gain unanimous support throughout the nation. In 1973, it was found that

Fourteen jurisdictions have accepted or have indicated that they are receptive to the view that legislation based solely on aesthetic considerations is valid. The plurality view, held by twenty-three states, is that an ordinance based solely on aesthetic considerations is not valid, but that aesthetic legislation is valid if it also serves some other legitimate interest. In fourteen states no case has been found in which the status of aesthetic regulation was before the courts. Thus, while aesthetic legislation has gained substantial support in recent years, only a minority, although an increasing minority, of states will uphold it even where other interests are not served as well.51

51 Note: "Beyond the Eye of the Beholder: Aesthetics and Objectivity," 71 Michigan Law Review, 1440-42 (June 1973). 
The dicta and decisions in cases involving sign control, blight, and visual nuisance conditions indicate that zoning for aesthetic objectives is within the police powers of the state. ${ }^{52}$ However, the cases regarding these issues concern activities which, in some way, either produce or have the potential of producing, harm to the public, i.e., loss of income, ugliness, or disruption to living patterns in the community.

In landmarks litigation, it is difficult, at best, to specify or quantify harm or improvement to the public in comparison to enumerating the costs of preserving the landmark to the owner. As a rule, the private sector is not legally obligated to provide the public with benefits at the private sector's expense. 53

The social and economic value of landmarks preservation is still unknown, and preservationists have yet to develop persuasive or objective arguments to support their positions. To date, a cogent assessment of the effects of historic preservation on communities--the direct and indirect costs and intangible benefits--does not exist.

In the New York City cases, the constitutionality of the Landmarks Preservation Law has been upheld by the courts. It is the application of the law which has not fared well and which prompts a major question for land use controls: When do regulatory actions constitute a "taking" of private property without just compensation?

${ }^{52}$ Berman v. Parker, 348 U.S. 26, 75 S. Ct. 98,99 L. Ed. 27 is the most well-known case and is used broadly. In New York, refer to People v. Stover, 12, N.Y. 2d 462, 191 N.E. 2d 272, 240 N.Y.S. 2d 734 (1 1963$)$, Appeal dismissed 375 U.S. 42, $84 \mathrm{~s}$. Ct. 147, 11 L. Ed. 2d 107; Cromweil v. Ferrier, 19 N.Y. 2d 263, 225 N.E. 2d 749, 279 N.Y.S. 2d 22 (1967); le v. Goodman, 31 N.Y. $2 d$ 262, 290 N.E. 2d 139, 338 N.Y.S. $2 d 97$

53 53 See Allison Dunham, "A Legal and Economic Basis for City Plan-
ning," 58 Columbia Law Review 650 (1958). 
The Court of Appeals in the Lutheran Church case refused to declare the municipal preservation law outrightly unconstitutional.

The decision in Matter of Sailors' Snug Harbor v. Platt (29 AD 2d 376), al though inconclusive on the question of confiscation since further facts had to be developed, is correct in refusing to declare the entire law unconstitutional on its face. The question posed there was whether in that instance regulation went too far. The buildings there sought to be preserved had become inadequate for their charitable purpose and were to be replaced. The Appellate Division ruled that where designation would prevent or seriously interfere with the carrying out of the charitable purpose it would be igyalid. That is a simple enough concept and ought to apply here.

In declaring the landmarks statute unconstitutional as applied, the lower court in the Penn Central case stated that:

The point of decision here is that the authorities empowered to make the designation may do so but only at the expense of those who will ultimately have to bear the cost, the taxpayers. 55

The line between proper and improper public regulation in landmarks cases, however, is still unclear. In the Appellate Division, the Penn Central court preferred to employ a constitutional test other than that proposed in Sailors' Snug Harbor: if the designation restricts the property to the extent that it cannot be used for the. sole purposes stated by its owner, then it should be de-designated or financially supported by the public. Instead, the majority held that

At best, they (plaintiffs) have shown that they have been deprived of the property's most beneficial use. . . The validity of the Landmarks Preservation Law, as applied to Grand Central Terminal, does not depend on showing that the landmark parcel will be undiminished in any degree by the regulation's restrictions: only that it will not 'deprive the individual property owner of

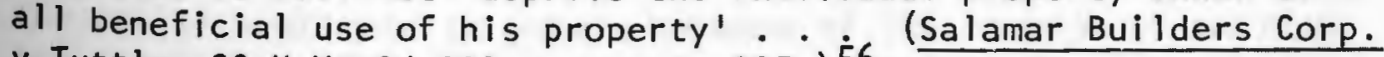
v. Tuttle, 39 N.Y. 2 d 221 , supra at 225.$) 56$

54 at 916 .

Lutheran Church 35 N.Y. 2 d at 131,316 N.E. 2 d at 311,359 N.Y.S.

55

Penn Central, N.Y.L.J., January 23, 1975.

${ }^{56}$ Penn Central, N.Y.L.J., December 18, 1975, P.4. See also Gold- 
The unusual financial structure of Penn Central and the prospect that the case will be appealed again prompt this author to regard the basis of the current decision in the case as one which will not stand favorably in future landmarks litigation. In all likelihood, the constitutionality tests which will be more frequently used in landmark cases will be:

(1) for tax-exempt institutions, if the designation imposes restrictions on the property to the extent that the regulation interferes with the charitable purposes of the owner, and

(2) for profit-making owners, if the designation imposes restrictions on the property to the extent that the regulation makes the property incapable of earning a reasonable return.

The City's preservation statute has also been challenged on the grounds that it denies the owner's equal protection of the laws. That the preservation statute results in non-uniform treatment of property owners without a reasonable basis is a contention that has emerged in two forms.

First, the dissenting opinion in the Penn Central case referred to the different classes of owners which are established under the Landmarks Preservation Law as arbitrarily conceived.

It will be recalled that Penn Central is precluded from seeking relief available to others because of its receipt of partial tax exemption. The statutory scheme, wi thout explanation therefore, treats differently three classes of landmark owners. Penn Central is relegated to that category which cannot obtain relief

Ltt v. Hempstead, 369 U.S. 590 (1960), where a town ordinance resulted the inability of the property owner to operate his gravel pit. FindThi that the property could be used profitably in other ways, the court upheld the constitutionality of the regulation. 
from the Landmarks Law. Moreover, as demonstrated by plaintiffs, there is neither a common thread nor a common sense segregation of classes of property. It is this feature which denies to plaintiffs the equal protection of the lawsy. The power of classification cannot be arbitrarily exercised. 57

Second, the application of the statute was successfully attacked on the grounds of violating the owner's equal protection of the laws in the Ethical Culture case. The court held that "the Commission's action as applied to this plaintiff was arbitrary, and unreasonable" after finding "that the building designated and that part of the property not designated are integrated in structure and function." In fact, the court stated that, "From the record, I can find no substantial evidence that the 'Meeting House' is an architectural masterpiece, or of significant historical value."158 Until the Ethical Culture case, the Commission had been successful in defending its actions with respect to the equal protection laws. 59

It is likely that "spot zoning"60 allegations will become more frequent and more serious in the future. Since a landmark must be at least thirty years old, the Commission began its designations with the oldest of the City's stock. In the next few years, the Commission will undertake the designation of more modern architecture--styles and buildings which are the subjects of mixed academic criticism and assessment. Controversies over the merits of newer structures have not had time to be resolved. For example, in the past 100 years, agreement over what constitutes a

57 Penn Central, N.Y.L.J., December 18, 1975, P. 16. ${ }^{58}$ Matter of Society for Ethical Culture, N.Y.L.J., December 24, 1975. 59 Manhattan Club, footnote 33, and Lutheran Church, footnote 34 , supra.

60 "Spot zoning" is the term used when a regulation unfairly discriminates between similar parcels of land, consequently denying an owner the equal protection and due process of the laws (U.S. Constitution, Amendment $x(V)$. 
good Greek Revival building (c. 1830-1860) has been established; a consensus on the worth of individual Art Deco structures (c. 1925-1945) has not yet been reached. Consequently, extensive disagreement among architectural historians on the Commission's designations may occur more frequently and may contribute to legal disputes concerning the reasonableness of the designation.

\section{E. Conclusions}

1. Federal legislation, by itself, does not guarantee, legally or financially, the protection and preservation of historic properties .

2. Through enabling legislation in New York State, localities have the authority, at their option, to adopt laws which regulate the treatment of historic properties.

3. The New York City Landmarks Preservation Law, which is considered to be a sound statute and which has initiated a strong landmarks program in the City, has been successfully challenged in litigation.

4. Two constitutional issues are problematic for landmarks preservation at the local level: the taking of private property without just compensation and the violation of private property owners' equal protection and due process of the laws.

5. Given the practical and legal difficulties of landmarks preservation in New York City, the preservation statute in New York City needs to be restructured. 
CHAPTER III: APPROACHES FOR STRENGTHENING LANDMARKS PRESERVATION IN NEW YORK CITY

\section{A. The Ad Hoc Committee to Strengthen the Landmarks Preservation Law}

The New York State Court of Appeals' decision for the Lutheran Church case in July of 1974 prompted great concern over the future of landmarks preservation in the city. Subsequent to the announcement of the ruling, members of the Board of Directors of the Landmarks Conservancy organized a committee ${ }^{1}$ to develop approaches and specific proposals for improving the City's landmarks statute.

At the first meeting of the Committee, discussion focused on the formulation of amendments which would restore the constitutionality of the City's preservation law as it applied to charitable institutions. No approaches or specific proposals were developed at that meeting, with the exception of suggestions posed by Michael Gruen in a letter of October 7, 1974:

A test comparable to that for commercial properties should be developed and enacted. This might provide that if the property is capable of earning a reasonable return, or if it is capable of con-

1 Members of the original committee included: Michael S. Gruen, Esquire (member of the Board of the Conservancy; attorney for the Amicus Curiae in the Lutheran Church case); Edgar A. Lampert, Esquire (member of the Board of the Conservancy; Executive Vice President of the New York City Community Preservation Corporation; drafted and implemented the air rights transfer plan for the South Street Seaport Special Zoning District); Ralph Menapace, Esquire (senior partner in the firm of Cahill Gordon \& Reindel; attorney for the Amicus Curiae in the Penn Central case); Dorothy Miner, Esquire (staff attorney for the Environmental Defense Fund, a public interest law firm); Anthony J. Newman (Executive Director of the Conservancy); and Whitney North Seymour, Sr., Esquire (member of the Board of the Conservancy; senior partner in the firm of Simpson Thacher \& Bartlett; drafted the New York City Landmarks Preservation Law). 
tinued use for non-commercial purposes, it may not be demolished. If the Commission does not find the above tests to be met, the Commission should have a reasonable amount of time (as in the case of commercial properties) to find a buyer or develop other means of preserving the property. The emphasis of any test should be the usability of the property in general rather than the plaintiff's peculiar requirements since the latter can be easily and satisfactorily resolved by selling the property if the test of the general usability can be met.

Embodied in Mr. Gruen's statement are two notions for changing the preservation laws, which for the purposes of this writing are identified as Committee Approaches 1 and 2:

(1) that the standard for judging hardship for charitable institutional owners of landmarks entail the concept of general usability; and

(2) that the Landmarks Preservation Commision be granted a reasonable period of time in which to devise a preservation plan for the structure which is acceptable to the owner.

Legislation for the second point was drafted and circulated among the members of the Committee, but few comments followed and no action was taken. The reason for this, perhaps, was the decision of the trial court in the Penn Central case which came forth in December of 1974. At the suggestion of Whitney North Seymour, Sr., the Committee reconvened in the spring of 1975 with Edgar Lampert as chairman. In addition to the original members of the Committee, Mr. Lampert asked representatives of the City's Corporation Counsel, as well as Donald Oresman, a member of the Board of Directors of the Conservancy and a senior partner in the firm of Simpson Thacher \& Bartlett, to join in the discussion. It should be noted that Dorothy Miner, in a new position, represented the Landmarks Preservation Commission, and this author, as a staff member of the Conservancy, were present at the meeting.

The group concluded that, in addition to Mr. Gruen's suggestions, 
the following points should be investigated:

(3) the transfer of a tax abatement to a taxpaying property owned by a tax-exempt landmark landlord;

(4) changes in the air rights transfer laws in the City;

(5) the integration of landmarks preservation into the City's master plan and zoning ordinance; and

(6) the establishment of a City agency to lease space in and manage landmark properties.

The initiation of two research projects obviated the need for further meetings of the Committee until the results of the studies, now scheduled for completion in 1977, were known. The Landmarks Preservation Commission received funding for a project which explores the economic impact of designation on property owners in historic districts and aims to devise new economic, legal, and institutional means for encouraging landmarks preservation. The second study, directed by Edgar Lampert and under the auspices of the Landmarks Conservancy, evaluates preservation and rehabilitation policies and programs in six urban areas across the country. Based upon the experiences of other cities, the project.seeks to develop appropriate municipal and citizen actions in the field of preservation.

The six approaches to improving the Landmarks Preservation Law posed by the Committee reflect the thinking of a group of highly respected experts in the area of preservation law and merit discussion, at this time, for three reasons.

First, on their face, the approaches generally respond to the major problems of landmarks preservation in an appropriate and practical manner. Second, the thinking of the Committee will certainly be incorporated into the studies which are now in progress; that the Committee, for all intents and purposes, became defunct before generating specific 
legislative proposals is not important. The principles and ideas of the Committee will be dealt with in the Commission's and the Conservancy's research projects and, therefore, remain active preservation concerns which will be scrutinized at a later time. Third, the endorsement by the members of the Committee of any legislative proposals which develop from the studies will greatly enhance the possibility of passing statutes that strengthen the preservation law. In this regard, the representation of both the public and private sectors on the Committee will be helpful in a political sense. It is likely that, upon the completion of the studies, the Committee will convene again to comment on and revise any legislative proposals which result from the projects.

A preliminary analysis and evaluation of the Committee's approaches, at this time, will serve to complement the work in the studies and, perhaps, anticipate some of the difficulties in restructuring the City's preservation laws.

\section{B. Structure for Assessing the Approaches}

The framework for evaluating the approaches for strengthening landmarks preservation in New York City consists of the ability of the suggestions to respond to certain of the problems of historic preservation discussed in Chapters 1 and 11 . The following questions will serve as bases for assessing the approaches:

(1) "Taking" Issues

(a) Will the approach encourage the free and economic use of a landmark property owned by a charitable institution, to the extent that the restrictions resulting from the application of the preservation law will not interfere with the owner's ability to carry out its purposes? 
(b) Will the approach enhance a commercial landmark property owner's capability of earning a reasonable economic return?

(2) Equal Protection and Due Process of the Laws

Will the approach foster a uniform and reasonable application of the Landmarks Preservation Law?

(3) Practicability

(a) Is the approach consistent with existing policies and laws to the extent that it will be legally and politically acceptable?

(b) Will the approach be a financially and administratively feasible undertaking for the City?

(c) Will the approach provide a workable solution to the real estate and market problems of saving landmarks?

Subsequent to discussions of the response of the approach to the above questions, the following conclusions will be stated in a chart:

Inconclusive by Itself:

Minimal Effectiveness:

Yes:

No:

c. Critique
The approach requires additional procedures or testing to determine its effectiveness.

The approach may, to a small extent, respond positively to the question.

The approach responds positively to the question and may be a useful strategy.

The approach responds negatively to the question and may result in adverse consequences for the City or preservationists.

Approach 1: That the standard for judging hardship for charitable institutional owners entail the concept of general usability.

The first approach is directed toward saving non-commercial landmarks, 
such as the Morgan Library or the School for Ethical Culture, which no longer serve their present functions and which are slated for demolition and replacement by a new structure. An amendment to the preservation law would be required and would state that a landmark owned by a charitable institution may not be altered or demolished if the building can be appropriately preserved in another use. The approach suggests two further needs: the promulgation of administrative guidelines to evaluate the "usability" of the landmark and, perhaps, the location of a substitute site which is adequate and acceptable for use by the institutional owner.

The approach would afford additional time in which to arrive at or negotiate a solution to saving the landmark; however, the approach would not necessarily guarantee a solution to the first "taking" question. In the event that a new use cannot be found for the landmark and in the event that a suitable development lot cannot be found for the owner, the determination that the structure is "usable" is insufficient to meet the current judicial test of hardship for this class of landmarks.

Approach 1 is similar to that which is provided for commercial owners in the City's preservation statute. ${ }^{2}$ Various departments in the Economic Development Administration, the Housing and Development Administration, and the Municipal Services Administration of the City engage in relocation and development activities, but do not extend their real estate functions to the preservation of landmarks. The Landmarks Preservation Commission does not have the staff capability to undertake brokerage work and, while an active real estate agency would be an asset to the city, it is not, at the present time, within the City's means to add more pro-

${ }^{2}$ New York City Charter, Ch. 8-A, §§207-8.0(i). 
fessionals to its payroll or to create a new agency. 
Approach 1: That the Standard for Judging Hardship for Charitable Institutional Owners Entail the Concept of General Usability

(1) Taking Issues:
(a) allows charitable institutional
owners to fulfill its purposes
Inconclusive by Itself
(b) enhances capability of earning a reasonable return on commercial properties
No

No

(2) Equal Protection and Due Process: fosters uniform and reasonable application of law

(3) Practicability:
(a) consistent with existing laws
and policies
Yes
(b) financially and administratively
No feasible undertaking for the City
Inconclusive by Itself
(c) provides a workable solution to real estate and market problems of saving landmarks

Summary: Requires further investigation and refinement 
Approach 2: That the Landmarks Preservation Commission be granted a reasonable period of time in which to devise a preservation plan for the structure.

This proposal is derived from the existing provision, previously mentioned, in the preservation law which affords the Landmarks Preservation Commission an opportunity to secure a tenant or a buyer who will use and preserve the landmark. The existing procedure involves landmarks that will be sold or leased; in this regard, Approach 2 would extend the Commission's powers to institutionally held landmarks which are slated for demolition and replacement by a structure on the site. In this instance, Approach 2 elicits the same conclusions as Approach 1.

In certain cases a preservation plan may be useful in protecting landmarks on development lots by providing guidelines for the incorporation of the significant architectural elements of the old building into a new structure. ${ }^{3}$ Once again, this work places extensive administrative burdens on the Landmarks Preservation Commission.

3The Landmarks Preservation Commission, pursuant to the City Planning Commission's draft legislation for landmarks on development lots which is presently under consideration as Section 74-712 of the Zoning Resolution, has devised such a plan for the landmark Villard Houses. 
Approach 2: That the Landmarks Preservation Commission Be Granted a Reasonable Period of Time in which to Devise a Preservation Plan for the Structure

(1) Taking Issues: (a) allows charitable institutional
owners to fulfill its purposes
Inconclusive by Itself
(b) enhances capability of earning a reasonable return on commercial properties

(2) Equal Protection and Due Process:

No fosters uniform and reasonable application of law

(3) Practicability:
(a) consistent with existing laws and policies
Yes
(b) financially and administratively
feasible undertaking for the City
No
(c) provides a workable solution to of saving landmarks real estate and market problems
Minimal Effectiveness

Sumary: May be a useful technique in the future; deserves further consideration 
Approach 3: The transfer of a tax abatement to a taxpaying property owned by a tax-exempt landmark owner.

In April 1975, this author completed a survey of the tax status of individually designated landmarks in Manhattan. Using ownership and tax information in the Real Estate Directory of Manhattan, 72/73, it was found that:

(1) of the 170 individually designated landmarks in Manhattan, 58 (32\%) were tax-exempt and owned by 52 private institutions (50 (28\%) properties were tax-exempt and owned by public agencies); and

(2) of the 52 private institutions, 8 (15\%) held other properties in the borough which were taxable.

In addition to the conclusion that Approach 3 would affect a small number of landmark properties, the City would be reluctant to institute a law which would further decrease its property tax revenues. 
Approach 3: The Transfer of a Tax Abatement to a Taxpaying Property Owned by a Tax-Exempt Landmark Owner

(1) Taking Issues:

(a) allows charitable institutional

(b) enhances capability of earning a reasonable return on commercial properties

(2) Equal Protection and Due Process: fosters uniform and reasonable application of law

(3) Practicability:
(a) consistent with existing laws
Yes and policies

(b) financially and administratively feasible undertaking for the City

(c) provides a workable solution to real estate and market problems of saving landmarks
Minimal Effectiveness

No

No

No

Minimal Effectiveness

Summary: Impact is too limited to warrant further consideration 
Approach 4: Changes in the air rights transfer laws in the city.

The Committee discussed two measures regarding air rights transfers: extending the ownership and geographic limitations on areas to which air rights may be transferred and establishing a "bank" to acquire and hold air rights.

The purposes of strict constraints on air rights transfers are, first, to maintain density and urban design standards in an area and, second, to avoid windfall-wipeout situations. These factors must be given serious consideration in any scheme to permit the transfer of air rights to areas which are not designated by the Zoning Resolution to receive more bulk.

Whether districts or specific lots are made eligible to receive air rights, the approach contains problems which are additional to those of achieving density and urban design goals: In the Fred French case, the court held that the mere enabling of air rights to be conveyed to another district was insufficient compensation for the economic loss resulting from the new zoning. law because these "floating" air rights did not have an estimable value. ${ }^{4}$ A similar. concern would exist if specific lots were designated; air rights can only be valued when a buyer makes an offer. Conversely, the assignment of air rights for transfer at a later date to a specific lot may stimulate development and cause a windfall for some property owners. In this event, the benefits which result from the preservation of the landmark do not accrue to the party which has incurred losses.

The "banking" of air rights, ${ }^{5}$ conceptually, is a more acceptable $\frac{\text { New York Law Journal, May } 25,1976 \text {, page } 11 \text {. }}{{ }^{4} \text {. The City of New York, }}$ 
opproach for saving landmarks because "the owner of the granting parcel may be allowed just compensation for the development rights, instantly and in money."6 Two obstacles exist to the formation of "banking" schemes in New York City: the uncertainty of and lack of confidence in the market for future sales ${ }^{7}$ which deters private institutions from buying air rights, and the financial inability of the city to establish and implement a banking mechanism.

air rights, see John J. Costonis, Space Adrift, Saving Urban Landmarks through the Chicago Plan (Urbana, 111: University of Illinois Press, 1974).

6 Fred F. French Investing Company, op. cit.

7 See the discussion of the Special South Street Seaport District, where a consortium of banks are holding the air rights, in Chapter 11 . 
Approach 4: Changes in the Air Rights Transfer Laws in the City

(1) Taking Issues:

(a) allows charitable institutional owners to fulfill its purposes

Minimal Effectiveness

(b) enhances capability of earning a reasonable return on commercial properties

(2) Equal Protection and Due Process: fosters uniform and reasonable application of law

(3) Practicability:

(a) consistent with existing laws No and policies

(b) financially and administratively feasible undertaking for the City

Minimal Effectiveness

No

(c) provides a workable solution to real estate and market problems of saving landmarks

No

No

Summary: The formulation of a new statutory scheme for development rights transfers requires extensive investigation and, in the end, may not be useful for most landmark cases 
Approach 5: The integration of landmarks preservation into the City's master plan and zoning ordinance.

The Committee's discussion of this approach focused only on a single purpose: to provide a rational basis, which will meet judicial tests for the equal protection provisions of the laws, for landmarks preservation. The Committee did not suggest a means for doing so.

The legal success of historic districts accounts, in part, for the proposal of Approach 5. The integrity of historic districts has been consistently upheld and protected by the courts. ${ }^{8}$ That the de-designation of the single structure will detract from the character or economy of the district or that the inclusion of a structure in the district is rationally related to a "plan" are tenets which preservationists can substantively and forcibly argue. As such, "spot zoning" allegations are less likely, and historic districts have fared better than individually designated landmarks.

Implicit in Approach 5 is the notion of regulating landmarks preservation in a manner similar to other land uses, especially parks and recreational areas and air and water resources. Such a strategy would place the task of protecting architectural and historic resources in the City Planning Commission where the designation and regulation of landmarks would be considered in conjunction with other land use controls and with the exigencies of the surrounding area.

Gradually, landmarks preservation has become a concern of the City Planning Commission; with the exceptions of technical advice and the authority to designate structures as landmarks, the ability of the Landmarks

${ }^{8}$ Maher v. City of New Orleans, 371 F. Supp. 653 (E.D. La. 1974); Bohannan v. City of San Diego, 30 Cal. App. 3d 416, 106 Cal. Rptr. 333 (Ct. App. 4th Dist. 1973); Opinion of the Justices to the Senate, 333 Mass. 783,128 N.E. 2d 563 (1955); City of Santa Fe v. Gamble-Skogino, Inc., 73 N.M. 410,389 P. $2 d 13$ (1964). 
Preservation Commission to save landmarks is limited. In recent years, the Planning Commission has incorporated landmarks preservation into its neighborhood plans. It has also enacted special zoning legislation which satisfies the once mutually exclusive goals of development and historic preservation. 9

Approach 5 is occurring on a piecemeal basis now, and trends in the City indicate that the infusion of landmarks preservation into the planning process will continue. Under the Charter Revisions which became effective on July 1, 1976, community planning boards have a voice in all land use decisions; neighborhood "mini-plans" will replace the City's master plan (which never really existed). 10 These changes, coupled with the increasing number of special zoning districts overlaying the City, afford an opportunity to smoothly restructure the legal and administrative framework for landmarks preservation.

9The Special South Street Seaport District and the proposed legislation for the Villard Houses (footnote 3) are examples of such historic preservation zoning amendments.

${ }^{10}$ In Preliminary Recommendations of the State Charter Revision Commission for New York City, June, 1975, the Commission found that "the City needs flexible requirements and procedures that can accommodate various types of single or multipurpose plans for the development of the City as a whole and of its constituent communities. The current City administration has made good progress in this area, but the Charter should institutionalize the concept of diverse plans shaped to the needs of particular purposes and geographic areas. Comprehensive plans should also be opened up to increased community participation and be reviewed by a politically accountable body in addition to the Planning Commission." (p. 116). The Charter Commission's recommendation that "the Charter requirement for a Master Plan of the City shall be eliminated" was passed in the City's November 4, 1975 referendum. 
Approach 5: The Integration of Landmarks Preservation into the City's Master Plan and Zoning Ordinance

(1) Taking Issues:
(a) allows charitable institutional
Minimal Effectiveness owners to fulfill its purposes
(b) enhances capability of earning a reasonable return on commercial properties
Minimal Effectiveness

(2) Equal Protection and Due Process:

Yes fosters uniform and reasonable application of law

(3) Practicability:
(a) consistent with existing laws and policies
Yes
(b) financially and administratively feasible undertaking for the City
Yes
(c) provides a workable solution to real estate and market problems of saving landmarks 
Approach 6: The establishment of a City agency to lease space in and manage landmark properties.

As mentioned in the consideration of Approach 1 , the creation of an active real estate agency for landmarks in the city would be a useful and, in the long run, a profitable enterprise.

The recent City cutbacks, resulting from the fiscal crisis, have left many of its buildings vacant or underutilized; the City owns over 675 properties which have been identified as architecturally outstanding. 11

Along with the belief that the City contains more than enough agencies, the present lack of funds in the City to set up another office militate against the implementation of this proposal.

11 Finding of the Landmark Conservancy's "Public Building Inventory," scheduled for completion in the fall of 1976. 
Approach 6: The Establishment of a City Agency to Lease Space In and Manage Landmark Properties

(1) Taking Issues:
(a) allows charitable institutional owners to fulfill its purposes
Minimal Effectiveness
(b) enhances capability of earning a reasonable return on commercial properties
Minimal Effectiveness

(2) Equal Protection and Due Process: fosters uniform and reasonable application of law

(3) Practicability:
(a) consistent with existing laws and policies
(b) financially and administratively feasible undertaking for the City
(c) provides a workable solution to real estate and market problems of saving landmarks

Summary: Warrants further investigation 
CHAPTER IV: CONCLUSIONS AND SUGGESTIONS

\section{A. Expanding the Approaches}

As the summary charts in the previous chapter indicate, this author finds that most of the approaches for strengthening landmarks preservation in New York City are insufficient by themselves to significantly affect architectural conservation in the city. The major factor which accounts for the weaknesses in the proposals is, perhaps, the narrowness of the Committee's purpose as stated: to formulate solutions for endangered landmarks which will be subject to the rulings in the Lutheran Church and Penn Central cases. Generally, the Committee failed to consider the legal difficulties of landmarks preservation in the context of and in conjunction with principles in the areas of real estate, planning, and municipal administration. With the exception of Approach 5 (the integration of landmarks preservation into the City's master plan and zoning ordinance), the Committee framed particular remedies which were ill-suited to pervasive problems; the solutions to these problems demand fundamental changes in and improvements to the existing landmarks preservation program in the city.

The important legal problems of historic preservation--due process and the equal protection of the law and the taking issue--are not readily solvable. In spite of the inability of those concerned with historic preservation to devise practicable legislative responses to these longstanding difficulties, there are a large number of quasi-legal and nonlegal avenues open to strengthening historic preservation efforts. Such 
strategies, in fact, may work to lessen the frequency of violations of constitutional rights.

For example, the Committee did not address at least two important needs of preservationists which would obviate the formulation of statutory modifications to the City's preservation law for different classes of owners. First the preservation movement lacks an early warning system to detect threatened landmarks. ${ }^{1}$ often, landmark buildings become endangered by neglect, deterioration, underuse, or development pressures before the public is made aware of their peril; in many cases, legal actions serve as notices to preservationists and public agencies of the imminent jeopardy of a building. Eleventh hour efforts to salvage such structures frequently fail and result in a wasteful deployment of human and financial resources. A mechanism is required to assess and to monitor the status of landmark buildings and to provide adequate time for the public to devise alternative strategies to demolition and replacement. The Landmarks Preservation Commission is the most appropriate entity to undertake the operations of a data bank and the publicity of endangered landmarks; the citizenry, however, is the most able body to carry out efforts to save such structures. ${ }^{2}$ It is suggested that, in addition to devising new standards, e.g., usability, upon which to judge hardship cases, measures be taken to minimize the number of cases which are litigated by instituting sound planning techniques in New York City's historic preservation program.

$1_{A}$ study to establish an early warning system to uncover endangered landmarks is underway at the Landmarks Conservancy and scheduled for completion in the fall of 1976.

${ }^{2}$ Individuals and private organizations have, in the past, been more successful than governmental bodies in saving landmarks in New York City. Public agency assistance is required in all campaigns, but it is a rare event when a public agency will initiate a project. 
The second aspect which the Committee did not consider is the task of making investments in landmark buildings competitive with ventures which call for their destruction. Again, the Committee focused on overcoming legal attacks on the Landmarks Preservation Law in lieu of changing the conditions which prompted the lawsuits. Little attention was paid to the need for developing incentives for the preservation of landmark buildings, changing policies which encourage the demolition of landmark structures, or formulating a penalty system for owners who, by action or inaction, jeopardize landmarks.

Because the Committee convened only twice and because there are two full-scale research projects on similar subject matter currently underway, speculation on changes to the City's preservation statute is difficult, at best. Embodied in the Committee's approaches, however, are notions which merit further exploration and which are discussed below.

(1) Re-Use

Preservationists are looking more and more to the formulation and implementation of adaptive use proposals as the primary strategy for saving landmark buildings. While obstacles exist to recycling many structures, the development of economically sound uses which retain the important architectural and historic characteristics of landmark buildings presents a constructive approach to preserving landmarks. Not only are the goals of preservationists satisfied in adaptive use cases, but so are the economic requirements of real estate owners, developers, and investors. How, then, can the principle of adaptive use be incorporated into laws which encourage landmarks preservation?

The Committee touched upon the institutionalization of the 
adaptive use concept in Approaches 1 and 2 . In the first instance, the Committee considered the notion of a "usability" standard to test hardship for charitable organizations owning landmarks; but "usability" here is an abstraction and in need of a more refined and operative definition. The second approach, in which the Landmarks Preservation Commission is given a reasonable time period to devise a preservation plan for the building, is administratively impractical. There exists in New York City a partial solution to the problem of determining the re-use potential of a landmark building and the economic consequences for its owner.

In a current landmarks dispute, ${ }^{3}$ the Archbishopric of New York, the charitable institutional owner of the landmark Villard Houses, and its developer proposed on the landmark's site a new building which retained only the exterior designated portions of the Houses. Preservationists contended that in addition to destroying valuable interiors which are not officially designated as landmarks, the gutting of the Houses would adversely affect the preservation of the exteriors and that stipulations calling for the continuing use of the landmark be part of any public agency approvals. Since the owner and the developer of the proposed project requested great bulk and setback variances on the basis of the existence of the landmark on the site, the City Planning Commission drafted zoning legislation setting forth conditions, including landmarks preservation provisions, upon which the applicant could obtain a

${ }^{3}$ See Chapter 111 , supra note 3. 
special permit to enable the development. During the drafting process, the Planning Commission requested from the developer economic data verifying the need to build the structure as proposed. The developer's submission consisted of cost estimates for an "as-of-right" building and the proposed new structure, and it was concluded by the developer that the former plan was economically unworkable. In reviewing the comparison, the Planning Commission, in the absence of additional information, was only able to state that the figures were valid. Subsequently, as a probable result of community pressure to preserve and reuse the Villard Houses, the developer made significant floor area changes in his plans which contradicted his own economic analysis.

The Landmarks Conservancy, in its critique of the Planning Commission's draft legislation, ${ }^{4}$ suggested that a finding be included in the statute which states that upon application for a special permit the following information be submitted to the Planning Commission and be made part of the public record:

(a) a copy of all documents filed with the Landmarks Preservation Commission;

(b) a copy of each city, state, and federal survey, registration, or report for the landmark;

(c) at the earliest possible stage, a detailed statement of any demolition or alterations proposed for the landmark;

(d) at the earliest possible stage, a statement, including representative drawings and respective cost estimates, of reasonable alternatives to the proposed demolition or alterations.

Had such information been presented at the outset of the project, it is quite possible that the new building would now be under

4

Letter of June 28,1976 from the Landmarks Conservancy to the City Planning Commission. 
construction and that greater portions of the landmark would be preserved. The Conservancy's recommendation for a small impact statement was not made part of the proposed legislation.

It is suggested here that the Landmarks Preservation Law of New York City be amended to require an analysis of reasonable alternatives to major proposed actions which will adversely affect landmarks. The formulation of the impact statement should be the shared responsibility of the applicant and the City Planning and Landmarks Preservation Commissions. While NEPA does not apply in this case, certain precedents relating to impact statements under NEPA can be used to establish the parameters of this recommendation.

Although the trend has not been irrevocably established, the courts will probably apply the Greene County ${ }^{5}$ rationale and require agencies to prepare their own impact statements at an early stage of agency decision making. Yet the holding in Greene County does not appear to require the agency to bear all of the additional expense and conduct all the necessary studies; as long as the agency consults with appropriate parties and then prepares a detailed statement that accompanies the proposed action at every distinct stage of agency decision making, it is free to require state governments and private parties to supply information, hire consultants, conduct field studies, and seek other assistance in carrying out its responsibilities. The synthesis and evaluation of such information, however, must be done by the agency. 6

It is then the agency's task to determine whether the applicant's information is valid. Such work involves less cost than the full preparation by the agency of the analysis.

${ }^{5}$ Greene County Planning Board V. Federal Power Commission, 2E L R 10153.

${ }^{6}$ Frederick $R$. Anderson, NEPA in the Courts, A Legal Analysis of the Environmental Policy Act (Baltimore, Md.: The Johns Hopkins University ress, 1973) p. 195. 
"Fact-finding constitutes the bulk of time and expense involved in an adequate environmental assessment . . . significant costs associated with fact-findings may be shifted to the applicant."17

It may be argued that the institution of a mandatory environmental review procedure for historic properties will result in long project delays and additional costs to all parties. 8 These same consequences, however, arose in the Villard Houses case in the absence of a formal assessment. In light of the present procedures in New York City for public decision-making, the high cost of litigation, the possible irreplaceable loss of the landmark, and the proportionately small cost of the environmental study to the entire project, it is likely that an environmental review process will ultimately save money.

The incorporation of an environmental impact statement requirement in the City's law would adequately reflect recent developments in federal environmental and historic preservation law at the local level and would successfully achieve a number of preservation goals in a rational framework:

(1) Provide data upon which to assess the "usability" of the structure in terms of both the specific spatial requirements of the owner and the general economic viability of the building in other uses;

(2) transfer some of the costs of ascertaining the "usability" of the structure away from the government; and

(3) afford the public and private sectors adequate time and substantive information upon which to comment and to devise preservation plans which have not been previously considered.

7Comment, "Delegation of the Drafting of Environmental Impact Statements: Greene County Planning Board V. Federal Power Commission," 2 E L R 10160 as quoted in NEPA in the Courts at p. 195.

${ }^{8}$ Anderson, op. cit. pp. $54-55$. 
(2) Tax Structures

The Committee, as a consequence of the problem of financial relief for tax-exempt organizations, considered one proposal concerning tax policies in landmarks preservation. The members did not consider using the tax system as a means of deterring and seeking alternative strategies to the demolition of landmarks.

one such proposal has been described in a recent article. ${ }^{9}$ The author maintains that two existing public policies--the government's granting of tax advantages to charitable institutions and historic preservation--are in conflict and that a possible resolution lies in invoking "limitations on exemptions in the form of explicit statutory language." 10 it is suggested that an organization retain its property tax exemption on its landmark building only in return for a "covenant by the owner that the land and structures thereon will not be used contrary to the purposes and policies of the Landmarks Preservation Law."ll The owner may not, under this proposal, refuse the designation and is subject to all other administrative requirements in the law.

The thinking behind this scheme is that, with the possibility of losing the organization's property tax exemption for the site and building, an owner will seek additional means for preserving its structure. "It is not the purpose of the

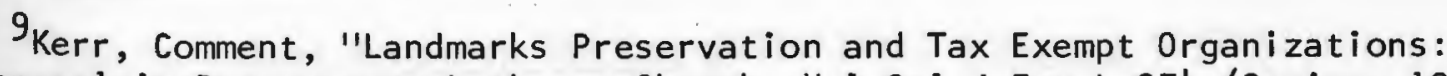
A Proposal in Response to Lutheran Church, "I Col J Env L 274 (Spring, 1975). 10 Id. at 300 .

11 Id. at 301 . 
proposal to strap an organization with a landmark whose preservation would contravene its purposes. Rather, the proposal encourages the owner to seek a purchaser or lessee who can use the landmark. "12 If a buyer or tenant cannot be found, the owner can alter or demolish the property without violating the covenant or the Landmarks Preservation Law.

The author of the proposal points out an implementation problem which limits the effectiveness of the suggestion: That the tax-exempt status of certain institutions is mandated by a state law $^{13}$ or a provision in the New York State Constitution. ${ }^{14}$ Municipal legislation which results in the taxing of properties receiving exemption under these laws would be in conflict with state law; either amendments to the state statutes are required or the impact of the preservation proposal is severely constrained to that portion of charitable institutions which secure exemptions under other statutes.

A solution for preserving charitable, institutionally-owned landmarks which are endangered by replacement is not readily available; stronger stipulations concerning the disposition of tax-exempt landmarks, however, can be instituted. Such property presents a great loss in the City's tax revenues over the years; the destruction of a landmark is a less tangible, but nonetheless real, cost. A recommendation of Toronto's Planning Board 15

?2Id. at 306 .

${ }^{13}$ New York Real Property Tax Law $\$ 421$ (1)(a), McKinney (1972). 14 New York State Constitution, Article XVI.

${ }^{15}$ City of Toronto Planning Board memorandum of September 25, 1974. The Board's recommendation to secure back taxes, with interest compounded, applied to all tax-exempt properties converted to revenue-producing uses. 
suggested that owners of tax-exempt landmark structures enter into an agreement with the city to preserve the buildings for a specified period of time. ${ }^{16}$ A breach of this contract would result in the payment of all or a portion of back taxes, with interest compounded, provided that two findings are made:

(a) that there was an inadequate attempt to secure a substitute site for the organization and to reuse the landmark; and

(b) that the landmark will be replaced by a profit-making building.

This scheme would have significantly affected the Penn Central case; Penn's partial "tax-exemption over the years has amounted to $\$ 11,083,489 . " 17$ In the Villard Houses project, also, this proposal could have been used to preserve greater portions of the landmark. In this instance, upon leasing the development site to a profit-making entity, the charitable owner was required to pay taxes, which were passed on in part to the developer, in accordance with the present assessed valuation of the land and improvements. Had a statutory provision that back taxes be paid existed, the proposed legislation, which enables the new building and only minimally preserves the landmark, would have been very different.

${ }^{16} \mathrm{~A}$ precedent exists for this scheme in California, where property listed in the National Register of Historic Places or the California Register of $\mathrm{Historic} \mathrm{Places}$ may receive preferential tax treatment provided that the owner and the locality enter into a contract which stipulates that the owner will preserve and maintain the building for a 20 year period of time. Breach of contract results in either a fee of $50 \%$ of the assessed valuation of the property or an action to enforce the contract. Cal. Gov't. Code \$\$50280-89 (supp. 1975); Cal.Pub.Res.Code \$\$5031-33 (Supp. 1975). 
The establishment of a revolving fund for historic preservation with monies collected as penalties for demolishing landmarks would be an appropriate means for the disposition of such income. Sums received from the loss of one landmark would then be employed to save other landmarks. The revolving fund could also serve as a special source of purchase money for threatened landmarks such as the J.P. Morgan House and the Ethical Culture School which the City is empowered to condemn but is unable to do so for financial reasons.

While a revolving fund for historic preservation has yet to be created in the city, the framework of the tax penalty plan described above is similar to an existing arrangement in the Special Park Improvement District. ${ }^{18}$ There, as a condition for a special permit allowing design and bulk modifications to existing regulations for new buildings near certain identified parks, the applicant is required to make a monetary contribution to the maintenance of the park. The exchange of such funds for an aesthetic loss is an accepted public policy which can be applied to landmarks as well.

(3) Restructuring the Administration of Landmarks Preservation The Committee's Approach 5 considered the integration of landmarks preservation into the City's master plan and zoning ordinance, but did not prescribe any means for doing so. It is this author's belief that this proposal offers a sound direction for landmarks preservation, and the following implementation plan is suggested:

${ }^{18}$ New York City Zoning Resolution, Article IX, Chapter 2. 
(a) That the Landmarks Preservation Law be repealed and reenacted, with changes, as part of the City's Zoning Resolution;

(b). That the Landmarks Preservation Commission become a division of the City Planning Commission;

(c) That the landmark nominations of the new preservation commission be reviewed and approved by those departments within the Planning Commission responsible for formulating land use and neighborhood development plans and then incorporated into such plans;

(d) That more specific criteria for judging the merits of a building, site, interior, or district nomination be devised;

(e) That further landmark designations be halted until the Commission completes its city-wide survey; exceptions to this stipulation may be made upon the receipt of a determined number of petitions for a landmark's designation; and

(f) That a yearly quota for designation nominations be instituted; exceptions to this stipulation, also, may be made upon the receipt of a determined number of petitions for a landmark's designation.

The purpose of the first three points is to implant landmarks preservation in land use and urban design matters which are currently undertaken, for the most part, by the City Planning Commission. As stated in Chapter 111 , the Planning Commission is becoming more concerned with landmarks preservation, but must often defer to the jurisdictional authority of the Landmarks Preservation Commission. The strengthening of the relationship between landmarks preservation and community plans may clarify the Commissions' respective roles and effectively hamper attacks on the administration of the City's preservation law.

The next two prescriptions clearly seek to limit the Landmarks Preservation Commission's powers with respect to which buildings merit designation and to the number of structures designated. They also work to counter allegations that the Landmarks 
Preservation Law is not applied uniformly and denies owners the equal protection of the law. In the past, the Commission has held public hearings to consider the designation of buildings, sites, interiors, and districts as landmarks at the request of citizens and as a result of various surveys. A major portion of the City's landmarks are, in all likelihood, deserving of their designation; there are, however, a number of structures which are of landmark quality and have not been designated for a variety of reasons. ${ }^{19}$ Designations should be left less to the Commission's discretion and more to a strict set of standards and objective information upon which to base decisions. Together, the participation of the City Planning Commission in designation decisions and the increased selectiveness of the Preservation Commission in making nominations should work to reinforce substantively the designations and to make them less open to challenges.

The last point is predicated on the argument that the city is gradually becoming overwhelmed with landmarks. The Commission has designated over 450 individual buildings as landmarks and over 11,000 structures composing 27 historic districts. Many persons believe that with each new designation the importance of being designated is diminished. A balanced public policy is required, one which maintains the worth of existing landmarks and at the same time accommodates those other assets of the City

${ }^{19}$ The Landmarks Preservation Commission is reluctant to designate politically controversial buildings, such as Pier A, Tweed Courthouse, Association Residence, Towers Nursing Home, etc., which, under existing criteria, seem appropriate for designation. Each of the above structures is listed in the National Register of Historic Places. 
which will merit designation as time passes.

B. Additional Areas for Strengthening Landmarks Preservation

(1) Preservation Incentives

One of the most important concerns of preservationists is the need for inducements for conserving landmark buildings. The proposals described above are essentially deterrents to demolition; in many cases, owners cannot afford to maintain their historic properties. There are several partial remedies, some proposed and some already available, which encourage preservation.

The Historic Structures Tax Act (5.667), passed in the U.S. Senate in August, 1976, provides both positive incentives for preservation and discouragements for the demolition of historic structures. Among the bill's provisions are that:

(a) Owners of buildings improved by substantial rehabilitation may use accelerated depreciation methods in calculating depreciation deductions for both the buildings and the improvements.

(b) Owners of certified historic structures or structures in historic districts are not allowed to deduct as current expenses demolition costs and the amortized cost of a demolished historic building; rather, the cost must be added to the basis of the land.

(c) New buildings constructed on the site of a demolished historic building may use only the straight-line method of depreciation.

Other proposals which would complement the Historic Structures Tax Act and which would be of great encouragement for landmarks preservation are tax credits for investments in renovations and maintenance deductions for future repairs which are deemed

${ }^{20}$ Chapman, "Federal Tax Policy as Incentives for Preservation" in Preservation News Supplement, May 1976. 
to be capital improvements. ${ }^{21}$ As the Historic Structures Tax Act, these proposals need constituency support for enaction.

The donation of facade easements to governmental jurisdictions and not-for-profit organizations is another means for receiving federal income tax reductions. In return for giving the donee the right to control the architectural treatment of the facade, the grantor is entitled to deduct for federal income tax purposes the fair market value of the easement in the tax year in which the contribution is made. The preservation restriction becomes part of the property deed and is passed from owner to owner.

The Landmarks Conservancy has initiated an easements program but has had difficulty in securing a donation because the approval of the mortgagee is needed before such a covenant is made part of the deed. Banks and lending institutions are reluctant to make a commitment which would restrict the use of a property which may, at some time, revert to them. The participation of the mortgagee in the donation process presents a serious problem for easements programs. That the easement may significantly contribute to the stabilization and improvement of the neighborhood--offering better investment opportunities--is a longterm benefit which is not yet apparent to banks and savings and loan associations. However, with documentation of the results of easements programs in other municipalities, it may be possible to educate the financial community and to gain its support for 
easements programs.

The zoning system in New York City is another potential source of inducements for landmarks preservation. Presently, design and bulk modifications to zoning regulations are offered in exchange for the provision of public amenities--gallerias, arcades, plazas, and parks. The option of preserving landmark buildings should be included in this listing of public amenities. In areas of the City, especially near major parks, additional open space is unnecessary but often planned in order to obtain the maximum bonus floor area for the project. In such cases, it may be justifiable to condition bonuses on the preservation of a landmark in the surrounding area, or, alternately, to donate a reasonable sum of money to a revolving fund for historic preservation.

(2) Funding Sources

The need for a revolving fund for historic preservation in New York City is evident. With almost 12,000 City-designated landmarks and National Register properties and numerous other noteworthy buildings, the City can do little on a large-scale basis to ease the economic costs of preserving structures or to assist in subsidizing immediately endangered landmarks. In this regard, a revolving fund in New York City which would provide a stable cash-flow for landmarks would be a valuable asset.

In sections above, two means of financing the revolving fund were mentioned: monetary penalties collected from demolishing landmarks and contributions from zoning trade-offs. Donations from foundations, corporations, and individuals are another source of funds. It may also be possible to organize the 
financial community to invest in the revolving fund.

The Landmarks Conservancy and the City of New York are in the conceptual stages of forming a revolving fund to dispose of the profits from the redevelopment of the Federal Archive Building. In July, 1976, an application was filed with the federal government to transfer this federally-owned surplus historic property to the City at no cost under the provisions of the Surplus Property Act. 22 This law, which was discussed in Chapter I in conjunction with the Custom House, stipulates that any net revenues from the project must be used for historic preservation purposes. The plan, which calls for the City's leasing the building to the Conservancy for renovation, proposes that a revolving fund be established to fulfill the income disposition requirements of the statute. The revolving fund will be administered by the Conservancy, with the participation of the City, and will be capitalized with the proceeds generated by the reuse of the Federal Archive Building. It is anticipated that the revolving fund will be in operation in 1979.

Another potential source of funds for historic preservation is suggested by the New York City Community Preservation Corporation model. The Community Preservation Corporation is a private, not-for-profit corporation funded by a consortium of lending institutions, and undertakes an "affirmative action" program which makes money available to homeowners in two areas in the City: Crown Heights in Brooklyn and Washington Heights in Manhattan. These communities were identified by the City

${ }^{22}$ See Chapter 1, discussion of the Custom House. 
Planning Commission as stable neighborhoods which would decline if disinvestment trends in the areas continue. The Community Preservation Corporation contacts property owners and works with them in securing mortgages for home improvements. With high level bankers sitting on the Corporation's board, the organization is not subject to the fundraising problems typical of non-profit organizations.

The Community Preservation Corporation example should be followed by preservationists. In many cases funds to rehabilitate even the most financially workable buildings are unavailable.

"Two points of view have gained ascendency in the lending fraternity: (1) that new is good and old is bad, and (2) that the central city is going down the tube and suburban areas are where everybody wants to be."123

A mortgage pool for historic preservation in New York City, administered separately or in conjunction with a revolving fund, would be a practical and useful tool.

\section{(3) Public Education}

The preservation movement in New York City is active and fragmented. It is comprised, for the most part, of groups which are an outgrowth of larger arts organizations in the City and which are usually formed on an ad hoc basis to save an immediately endangered structure. For example, the "Committee to Save Grand Central Station" is rooted in the Municipal Art Society of New York and the effort to preserve the Association Residence Nursing Home is centered in the Architectural League of New York.

${ }^{23}$ Crissman, "Giving Lenders What They Need," Economic Benefits of Preserving 01d Buildings (Washington, D.C.: The Preservation Press, 1976) p. 126 . 
In spite of the growing participation in preservation, groups throughout the City have yet to unite and form an identifiable "community of preservation interests" which cogently articulates a workable set of goals for the movement. Each group seeks to protect, rather than share, its resources; the result is frequent duplication of work and competition in fundraising.

With the exceptions of the Landmarks Preservation, a public agency, and the Landmarks Conservancy, a private, not-forprofit organization, there are no city-wide entities which devote their efforts exclusively to historic preservation or which strive to formulate effective responses to broad preservation questions. The Commission and the Conservancy both conduct studies, inventories, and economic analyses to provide fundamental data and objective bases upon which well-founded public and private decisions can be made. Work in both offices is underway to develop practical techniques and efficacious policies which encourage historic preservation. Thus the Commission and the Conservancy undertake the major portion of planning activities in the field of historic preservation and constitute the core of the preservation movement in New York City.

Preservationists must first educate themselves about existing groups' resources in the City and develop structures which encourage cooperation in activities. This is not easy. Last year, the Architectural League and the Landmarks Conservancy co-sponsored two meetings to explore the creation of a Preservation Council in New York. Reaching out to city-wide groups which undertake preservation activities, the League 
and the Conservancy contacted over thirty organizations to participate in discussions which focused on whether such a structure was needed and, if so, what its purposes and framework should be. While the former question was answered in the affirmative, there was great disagreement on the latter. Groups, realizing that a central information organization would be valuable, feared also that a Council would require expulsion of funding resources and the subjugation of the groups' activities to a larger power. The need for a Preservation Council persists, but its institution demands great educational and organizational efforts which no public or private agency can capably undertake at present.

of great importance, also, is the need for preservationists to assess the consequences of their actions. To date, an objective evaluation of the effects of historic preservation on communities--the direct and indirect costs and intangible benefits--does not exist. Working with untested assumptions, preservationists are frequently faced with the following problems: (a) the reluctance of public and private funding sources to contribute to historic preservation efforts; (b) the absence of rational planning for historic preservation within the movement itself; and (c) the inability to incorporate historic preservation into the overall planning process of the City.

Once questions concerning the role of historic preservation in neighborhoods are clarified, potential funding sources can be persuasively solicited with substantive information, rather than rhetoric, and the formulation of a general method 
for landmarks preservation can begin. The success of such tasks necessarily depends upon the ability of preservationists to educate preservationists, members of governmental agencies, citizen groups, community planning boards, corporations, financial institutions, foundations, and the public at large.

\section{Summary}

This chapter concluded that three approaches of the Committee-changing the legal standard for judging hardship for charitable institutional landmark owners to include a concept of general "usability", granting the Landmarks Preservation Commission a reasonable period of time to devise preservation plans, and integrating landmarks preservation into the City's master plan and zoning ordinance--merit further investigation. In addition to these proposals, other suggestions which militate against the occurrence of major legal problems and which should be explored were presented:

(1) that the Landmarks Preservation Law be amended to require an environmental impact statement for those landmarks scheduled for significant alteration or demolition;

(2) that a preservation covenant be obtained from tax-exempt institutional owners of landmarks and that the failure to preserve the structure under prescribed conditions result in the loss of the organization's property tax-exempt status;

(3) that, subject to the terms of an agreement to preserve and maintain a tax-exempt landmark, the finding that there was an inadequate review of substitute sites or that the landmark would be replaced by a profit-making structure should result 
in the payment of back taxes, with interest compounded, on the property;

(4) that the Landmarks Preservation Commission be restructured as part of the City Planning Commission so that landmarks preservation can be integrated into the city planning process; and

(5) that the nominations of the Landmarks Preservation Commission for landmark designation be limited in quantity and quality.

In order to strengthen the landmarks preservation movement in broader senses, the following issues were also discussed:

(1) the securing of federal taxation incentives encouraging landmarks preservation: the Historic Structures Tax Act, investment tax credits and maintenance deductions, and donations of facade easements;

(2) the initiation of changes in the Zoning Resolution: the treatment of landmarks preservation as a public amenity;

(3) the creation of a revolving fund for historic preservation;

(4) the establishment of a mortgage pool for historic preservation; and

(5) the need for a public education program in the field of historic preservation.

The frameworks for landmarks preservation in New York City are we 11developed in some areas and favorably changing in others. It is clear, however, that new legal, economic, and planning means are needed to ensure the protection and preservation of the City's aesthetic resources. It is hoped that the proposals described in this thesis will provide preservationists with sound directions in which to pursue and successfully accomplish their purposes. 


\section{Bibliography}

Books:

Anderson, Frederick R. NEPA in the Courts, A Legal Analysis of the National Environmental Policy Act. Baltimore, Maryland: Johns Hopkins University Press, 1973.

Barnett, Jonathan. Urban Design as Public Policy. New York, New York: McGraw-Hi 11,1974 .

Costonis, John J. Space Adrift: Saving Urban Landmarks through the Chicago Plan. Urbana, Illinois: University of 111 inois Press, 1974.

Economic Benefits of Preserving 0ld Buildings, papers from the "Economic Benefits of Preserving 01d Buildings" conference of the National Trust for Historic Preservation. Washington, D.C.: The Preservation Press, 1976.

Morrison, Jacob H. Supplement to Historic Preservation Law. New Orleans, Louisiana: $19 \overline{72}$.

Moss, Elaine, editor. Land Use Controls in New York State, A Handbook on the Legal Rights of Citizens by the National Resources Defense Council, Ine. New York, New York: Dial Press, 1975.

\section{Reports:}

Economist Intelligence Unit, Ltd. Report: The U.S. Property Market. London, England: June, 1975.

Landmarks Preservation Commission Reports on Grand Central Terminal \#69005 and \#69006, August 26, 1969.

Preliminary Recommendations of the State Charter Revision Commission for New York City. June, 1975.

\section{Periodicals:}

Architectural Record. December, 1974 issue devoted to the adaptive use of old buildings.

Benzer, Shirley L. "Downtown, It's a Tenants' Market," New York Times, August 11, 1974. 
Carmichael, Donald M. "Transferable Development Rights as a Basis for Land Use Controls," Florida State University Law Review, Vol. 2, (Winter, 1974), p. $3 \overline{5}$.

Carruth, Eleanore. "The Skyscraper Losses in Manhattan Office Buildings," Fortune, (February, 1975), p. 78.

Chapman, Mortimer. "Federal Tax Policy as Incentives for Preservation," Preservation News Supplement, May, 1976.

Connecticut Law Review, Vol. 8, No. 2, (Winter, 1975-76), issue devoted to historic preservation.

Dunham, Allison. "A Legal E Economic Basis for City Planning," Columbia Law Review, Vol. 58, (1958), P. 651.

Fried, Joseph P. "Apartment Vacancy Rate is Placed at $2.8 \%$ in City," New York Times, November 13, 1975.

Gilbert, Frank. "Saving Landmarks: The Transfer of Development Rights," Historic Preservation, July/August, 1970, p. 13.

Horsley, Carter. "On Trial: The Courthouse," New York Times, July 25, 1976, Section 8, p. 1 .

Huxtable, Ada Louise. "The Housing Crisis," New York Times, November 18, 1975, p. 37.

- 'What's Best for Business Can Ravage Cities," New York Times, April 6, 1975, p. 30.

Ingle, B.J. "Corkscrew Sanctuary: Use of the Market for Preservation," Environmental Affairs, Vol. 3, (1974), p. 647.

Journal of Law \& Contemporary Problems, Vol: 36, (Summer, 1971), issue devoted to historic preservation.

Kaiser, Charles. "Prices of Buildings in Manhattan Falling Sharply," New York Times, October 28, 1975, Section 8, p. 1.

Kerr, John J., Jr. "Comment: Landmarks Preservation \& Tax-Exempt Organizations: A Proposal in Response to Lutheran Church," Columbia Journal of Environmental Law, Vol. 1, (Spring, 1975).

Marcus, Norman. "Mandatory Development Rights Transfers and the Taking Clause: the Case of Manhattan's Tudor City Parks," Buffalo Law Review, Vol. 24, No. 1, (Fall, 1974), p. 9.

"Note: Beyond the Eye of the Beholder: Aesthetics \& Objectivity," Michigan Law Review, Vol. 71, (1973), p. 1438.

Oser, Alan S. "Chrysler Building Facing Test," New York Times, October 15, 1975.

- "Hope for Renovation Surge Pointed on 'J 51 '," New York Times, November 14, 1975, p. 60 . 
- "Zoning Revisions to Expand Loft Conversions are Urged by

New York Real Estate Board," New York Times, October 29, 1975, p. 69.

Reed, Thomas J. "Land Use Controls in Historic Areas," Notre Dame Lawyer, Vol. 44, (1969), p. 379.

Robinson, Nicholas A. 'Historic Preservation: The Qualities of the ManMade Environment," New York Law Journal, May 28, 1974.

- "The Urban Applications of Environmental Precedents," New York Law Journal, June 24, 1975.

Sax, Joseph. "Takings and the Police Power," Yale Law Journal, Vol. 74, $(1964)$, p. 36 .

"Takings, Private Property and Public Rights," Yale Law Journal, Vol. 81, (1971), p. 149.

Schroeder, W.A. "Preservation of Historic Areas," Kentucky Law Journal, Vol. 62, $(1973-74)$, p. 940.

Skull, Joe A. "How to Use the Tax System to Promote Historic Preservation," Real Estate Law Journal, Vol. 4, (1976), pp. 398-415.

Stiles, Robert B. 'Note: Urban Landmarks: Preserving Our Cities' Aesthetic and Cultural Resources," Albany Law Review, Vol. 39, (1975), P. 521 .

Talbot, Allan B. "City's Top Planners Trapped in the Past," New York Times, December 28, 1975, Section 8, p. 1 .

Wolf, Edward A. "The Landmark Problem in New York," Intramural Law Review of New York University, Vol. 22, p. 107.

\section{Preservation Laws}

"An Act to Facilitate the Preservation of Historic Monuments, and for 0ther Purposes," Public Law 92-362, 84 Stat. 503-504, August 4, 1972, amendment to the Surplus Property Act of 1944.

"Antiquities Act of 1906," 34 Stat. 225, 16 U.S.C. \$\$431-33.

"Demonstration Cities and Metropolitan Development Act of 1966," 40 U.S.C. $\S 461$ (b) (1970).

"Department of Transportation Act of 1966," 49 U.S.C. $\$ 1653$ (b) (1970).

Executive Order \#11593, May 13, 1971.

'Historic Sites Act of 1935," 49 Stat. 666, 16 U.S.C. $\$ \S 461-7$.

"Historic Structures Tax Act," S. 667 (1976), enacted as amendment 1905 to the "Tax Reform Act of 1976." 
"Landmarks Preservation Law of the City of New York," Administrative Code of the City of New York, Chapter 8-A.

"National Environmental Policy Act of 1969," 42 U.S.C. $\$ 4331$ (b) (4).

"National Historic Preservation Act of 1966," Public Law 89-665, 15 U.S.C. $\S 470 ; 36$ C.F.R. $\$ 800$ et seq.

"National Trust for Historic Preservation Act of October 26, 1949," 63 Stat. 927,16 U.S.C. $\$ 468$.

New York City Zoning Resolution, $\S \S 74-7$.

Preservation Case Law

Fred F. French Investing Co., Inc. v. City of New York, 352 N.Y. 2d 762; Affirmed, New York Law Journal, May 25, 1976.

Lutheran Church in America v. City of New York, 35 N.Y. 2d 121, 316 N.E. 2d 305,359 N.Y.S. 2d 7 (1974).

Maher v. City of New Orleans, 371 F. Supp. 653 (E.D. La. 1974).

Matter of Manhattan Club v. Landmarks Preservation Commission, 51 Misc. 2d 556,273 N.Y.S. 2d 848, (1966).

Matter of Society for Ethical Culture in the City of New York v. Spatt, New York Law Journal, December 24, 1975.

Matter of Trustees of Sailors' Snug Harbor v. Platt, 29 App. Div. 2d 376, 288 N.Y.S. 2d 314, 29 A.D. 2d 376.

Penn Central Transportation Company, The New York $\&$ Harlem Rail road Company, The 51 st Street Realty Corporation \& UGP Properties, Inc. v. City of New York, (Sup. Ct.) New York Law Journal, January 23, 1975; (App. Div.) New York Law Journal, December 18, 1975.

Save the Courthouse Committee v. Lynn et al., (U.S.D.C., S.D.N.Y., March 6, 1975, 74 Civ. 5646, n.o.r.).

The State Historical Society of Colorado $v$. Board of County Commissioners of El Paso County et al., Civil Action No. 75-A-656 (United States District Court for the District of Colorado), Stipulation and Agreement for Dismissal, June 26, 1975.

United States v. Gettysburg Electric Ry. Co., 160 U.S. 668 (1896). 